Vol. 40(2), pp. 1-23, Dec. 2021

ISSN 1821-536X (print)

ISSN 2619-8789 (electronic)
Tanzania Journal of Engineering and Technology

Copyright $(\mathcal{C} 2021$ College of Engineering and

Technology, University of Dar es Salaam

Full Length Research Paper

\title{
Spatial and Temporal Variation of Selected Water Quality Parameters in the Tanzanian Side of Lake Victoria
}

\author{
R. R. Makaka ${ }^{1}$, Shepherd N. Misi ${ }^{1}$, Mhosisi Masocha ${ }^{1}$ and Richard J. Kimwaga ${ }^{2 *}$ \\ ${ }^{1}$ University of Zimbabwe, Department of Civil Engineering, P. O. Box MP 600, Mount Pleasant, \\ Harare, Zimbabwe \\ ${ }^{2}$ University of Dar es Salaam, Water Resources Engineering Department, P. O. Box 35131, Dar es \\ Salaam, Tanzania \\ 2*Email of corresponding author: rkimwaga2007@yahoo.com,or rjkimwaga@udsm.ac.tz
}

\begin{abstract}
Lake Victoria's water quality is increasingly becoming under heavy pressure mainly due to land based activities and aerial inputs which are taking place within the basin. This study was carried out to assess the spatial, including vertical and temporal, variation of the water quality of Lake Victoria on the Tanzanian side. Historical water quality data for the period from 2000 to 2016 was collected. Temperature, $p H$, Dissolved Oxygen (DO) and Turbidity were selected for study since they are the mostly measured and monitored water quality parameters. Land use-land cover changes were analysed using ArcGIS. ILWIS 3.7 software was used to classify the land use and land cover for the years 2000, 2010 and 2014. MERIS was used to analyse the spatial variation. One-way ANOVA was employed to test the significant variation between different parameters. The results showed that, for the pelagic zone, the range of temperature, $p H, D O$, and turbidity were $22.8^{\circ} \mathrm{C}-28.68^{\circ} \mathrm{C}, 6.3-10.52,3.42-10.21 \mathrm{mg} / \mathrm{l}, 1.0 \mathrm{NTU}-15.8 \mathrm{NTU}$ respectively. The corresponding values for the littoral zones were $22.3^{\circ} \mathrm{C}-26.8^{\circ} \mathrm{C}, 6.47-10.16$, 3.99-8.6 mg/l, 1.3-347 NTU respectively. The ANOVA analysis results show that there was a significant variation of $\mathrm{NO}_{3}(p<0.01)$. Temperature, $p H$ and $D O$ decreased with the lake depth to the bottom for both zones. For the littoral zone, a strong correlation was observed between temperature and depth, temperature and $D O$, and between temperature and $p H$ with $R^{2}=0.6$, $p<0.03, R^{2}=-0.78, p<0.01$ and $R^{2}=0.96, p<0.01$, respectively. The bare soil, urban settlements and farm land increased by $38.9 \%, 8.4 \%$ and $10.7 \%$ respectively from the year 2000 to 2014 on the Tanzanian side. This could have led to water quality changes. Water quality parameters varied significantly between pelagic and littoral zones. Littoral zones are mostly polluted and thus should be the priority pollution control intervention areas.
\end{abstract}

Key words: Spatial-temporal variation, water quality, strong correlation, land use change.

\section{INTRODUCTION}

The United Nations' (UN's) Sustainable Development Goals (SDGs) provides framework for sustainable management of our environment (UN, 2015). SDG target 6.3 seeks to improve water quality, wastewater treatment and safe reuse while SDG target 6.6 aims to protect and restore water-related ecosystems, including mountains, forests, wetlands, rivers, aquifers and lakes. Indicator 6.6.1 is the "change in the extent of 
water-related ecosystems over time" (UN, 2015). Lakes are important and sensitive ecosystems which must be sustainably managed to achieve the two SDG 6 targets (UN, 2015). Lake Victoria (LV) is recognized for its high levels of freshwater species diversity and endemism, which are of critical importance to local livelihoods and national economies within the basin (Semayo, 2021). This crucial ecosystem for the region is being plagued with frequent fish kills, oxygen depletion of deep waters and poor water quality, which is characterized by blooms of harmful algae and aquatic weeds (Semayo, 2021).

Most of the LV riparian populations depend on LV for various economic activities (Kayombo and Jorgensen, 2006). For example, along the shoreline of LV on the Tanzania side, there is a number of towns which depend on LV for their domestic, industrial and institutional water needs (Cheruiyot et al., 2014). These towns include, Mwanza City, Musoma and Bukoba Municipalities, Misungwi, Lamadi, Magu, Sengerema, Chato, Muleba and other District Councils (COWI, 2017). The total population of lake dependants is estimated to be more than 1,000,000 (Tanzania NBS, 2012). Also, though not good practice, LV is used as a disposal site for the untreated, partially treated and treated wastewater (COWI, 2002; Kayombo and Jorgensen, 2006; Cheruiyot et al., 2014).

Over the last three decades, the increase in population, urbanisation and economic growth have resulted in escalated anthropogenic pollution of the Lake Victoria (COWI, 2002; Kayombo and Jorgensen, 2006; Oyoo, 2009; Kimwaga et al., 2011). The rapid growth of the riparian community, industrialization and an increase in commercial activities, coupled with inadequate provision of sanitation services to the residents and towns around the lake has resulted into the increased effluent which then finds its way to the lake, thereby, causing pollution (Oyoo, 2009). Some of the rivers which feed the lake are polluted by municipal and industrial wastes (COWI, 2002).

The various LV water quality studies have been conducted focusing mainly on the water hyacinth and fishing activities (Scheren et al., 2000; Okungu et al., 2004; Kateregga and Sterner 2007; Kateregga and Sterner, 2009). The lake's water quality deterioration has not long been adequately addressed. Studies have also shown that the nutrients which enter the lake are mostly bound up within the bottom part of the lake, with little recirculation (Lehman and Branstrator, 1994; COWI, 2002; Boehrer and Schultze, 2008), causing water deterioration and eutrophication. Aquatic plant mapping within the lake has revealed that the aquatic plants in the lake have decreased, compared to the 1990's (Cheruiyot et al., 2014). Further, the lake has been polluted by nonpoint source of pollution (Kimwaga et al., 2011).

Despite the various efforts in addressing the water quality management challenges, there is still insufficient information on the spatial and temporal variation of water quality on the Tanzanian side of Lake Victoria waters. An understanding of the spatial and temporal variation of water quality will help in identifying the pollution hotspots areas needing immediate water quality intervention measures. Besides, the land use land cover factors which can be attributed to the changes of the water quality of the lake have not been well understood.

\section{METHODS AND MATERIALS}

\section{Description of Study Area}

This study was conducted in the Tanzanian side of the Lake Victoria (Figure 1).

The catchment area in the Tanzania side is $115,400 \mathrm{~km}^{2}$, the lake's surface area is $35,720 \mathrm{~km}^{2}$ and the length of shoreline is $1,150 \mathrm{~km}$. The rainfall in the eastern part of the Lake Victoria Basin, especially in highlands of Tarime, is distinctively bimodal. In the south portion, in Mwanza Region, the pattern is unimodal with a wet 
and dry season. The western part receives rainfall almost throughout the year with minimum rainfalls in July. There are considerable variations in the average yearly rainfall over the lake surface and the surrounding land area. Over the extreme eastern area of the lake, rainfall varies between 500 to $2000 \mathrm{~mm}$ per year. The main rivers draining into the lake include Kagera, Simiyu, Mbarageti, Grumeti, Mara and Mori Rivers. There are three transboundary rivers within the basin which are Mara, Kagera and Grumeti rivers and small rivers which are Mwisa, Ngono, Duma, Nyashishi, Suguti, Magogo, Moame and Mato rivers.

The Tanzania part of the lake basin contributes significantly to the welfare of many communities who rely on it as a source of food in terms of fish, employment, and trade (Kayombo and
Jorgensen, 2006). Besides food, the lake provides transport, communication, tourism, water supply for domestic, agricultural and industrial use, wastewater disposal, recreation, sports and biodiversity conservation (Kayombo and Jorgensen, 2006). The dominant socio-economic activities in the lake and its catchment include agriculture, fisheries, water transportation, recreation, and water supplies for domestic and industrial use in the urban centres on its shoreline (BICO, 2020). There are also Gold and Nickel mining activities being conducted in the basin including the presence of major mining sites like Geita Gold Mine and North Mara gold mine and local small-scale mining sites, which also have an impact on the environment (BICO, 2020).

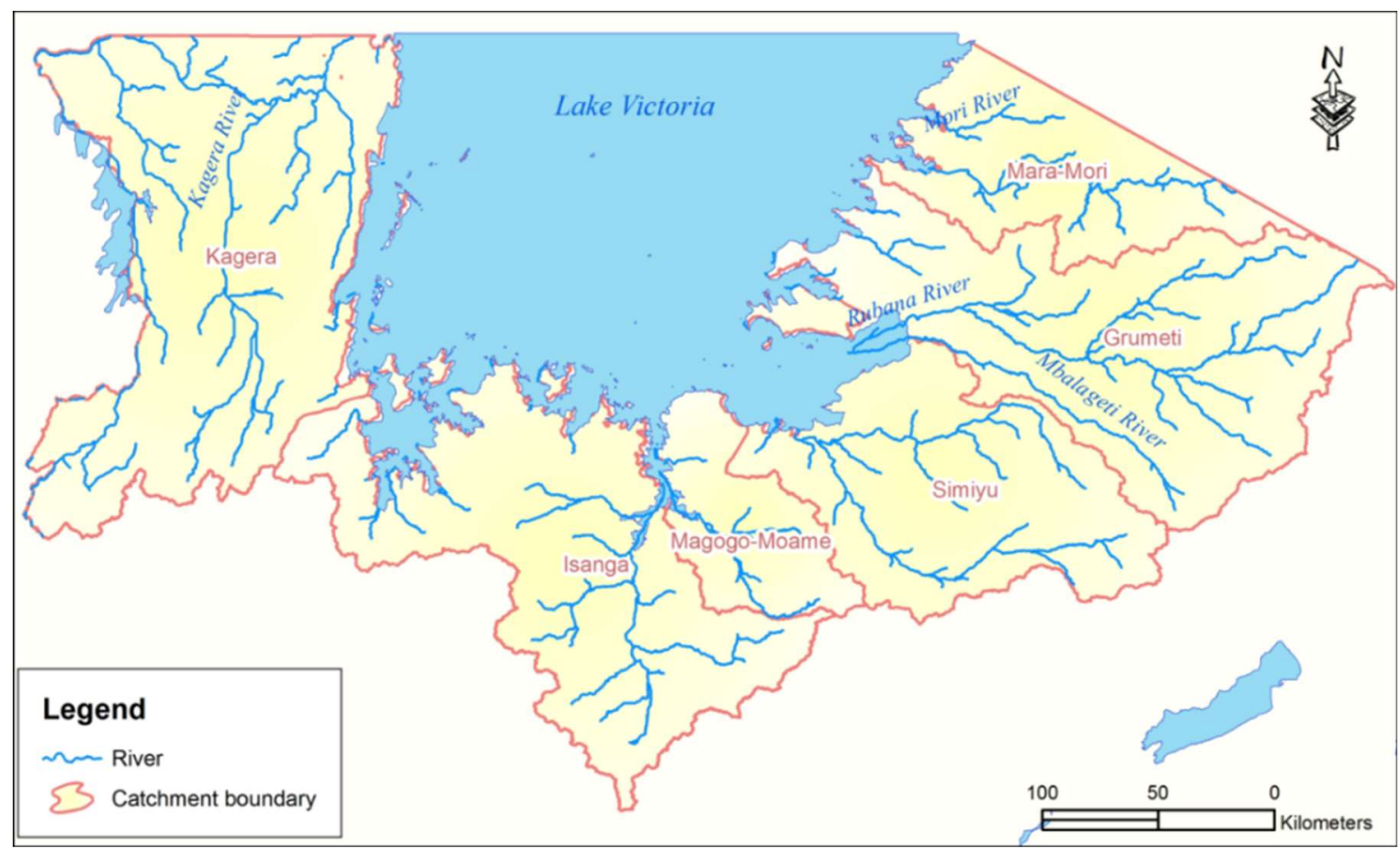

Figure 1: The map of the Tanzania side of Lake Victoria Basin (BICO, 2020)

The percentage contribution of rivers to Lake Victoria on the Tanzanian side basin and the whole basin of Lake Victoria is shown in Error! Reference source not found.. 
Table 1: River contribution to the Lake Victoria waters and catchment (Kayombo and Jorgensen, 2006)

\begin{tabular}{|l|l|l|l|}
\hline River name & Discharge $\left.\mathbf{~}^{\mathbf{3}} / \mathbf{s}\right)$ & $\begin{array}{l}\text { \% contribution for } \\
\text { Tanzanian side basin }\end{array}$ & $\begin{array}{l}\text { \% contribution } \\
\text { for whole basin }\end{array}$ \\
\hline Mara & 37.5 & 7.87 & 4.8 \\
\hline Grumeti & 11.5 & 2.41 & 1.5 \\
\hline Mbalageti & 4.3 & 0.90 & 0.5 \\
\hline E. Shore Stream & 18.6 & 3.90 & 2.4 \\
\hline Simuyu & 39.0 & 8.19 & 5.0 \\
\hline Magogo Moame* & 8.3 & 1.74 & 1.1 \\
\hline Nyashishi* & 1.6 & 0.34 & 0.2 \\
\hline Issanga & 30.6 & 6.42 & 3.9 \\
\hline S. Shore Stream* & 25.6 & 5.37 & 3.3 \\
\hline Biharamulo & 17.8 & 3.74 & 2.3 \\
\hline W. Shore Stream & 20.7 & 4.35 & 2.7 \\
\hline Kagera & 260.9 & 54.76 & 33.5 \\
\hline Sub-total & $\mathbf{4 7 6 . 4}$ & $\mathbf{1 0 0}$ & $\mathbf{6 1 . 2}$ \\
\hline
\end{tabular}

\section{Population around Lake Victoria}

According to NASA (2006), Lake Victoria basin is the most densely populated rural area in the world with a population of about 30 million. According to NBS (2012) statistics, about 1.5 million people are found on the Tanzanian side along the lake shore. The average density on the Tanzanian side is 97 persons $/ \mathrm{km}^{2}$ (UNEP, 2006). The population growth rate is about $6 \%$ per annum (Kayombo and Jorgensen, 2006).

\section{Data collection}

Historical water quality data from LVEMP data base from year 2000-2016 The water quality data which were used in this study were historical data which were collected from Lake Victoria Environmental Management Programme (LVEMP) database. The data are from the existing water quality monitoring points used by Lake the Victoria Basin Water Organization (LVBWO). LVBWO is an institution responsible for monitoring the water quality of Lake Victoria on Tanzanian side and advising the government on issues pertaining to water quality of Lake Victoria and other related activities in the lake's catchment. The data were for the two main zones, namely the open Tanzania Pelagic zone (TP), and the near shore areas herein referred to as the Tanzania Littoral zone (TL) (Figure 2).

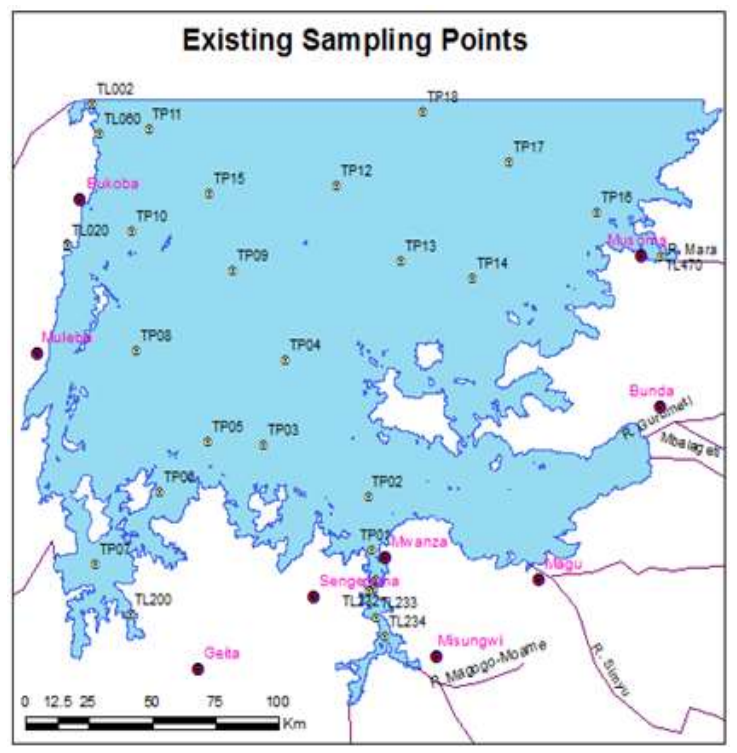

Figure 1: The water quality monitoring points for the Tanzanian side of the Lake Victoria (COWI, 2002) 
This classification is based on depths, with the pelagic area having depths greater than 15 metres and the littoral area having depth less than 15 metres. A total of 29 monitoring stations, out of which 18 are pelagic and 11 are littoral stations, as depicted in Figure 2, were considered in this work.

The water quality data collected were physicochemical lake water quality parameters which included Temperature, $\mathrm{pH}$, Turbidity, DO, EC, Nitrates and Chlorophyll- $a$. The Standard Methods for Examination of Water and Wastewater (APHA, 2000) were used for the analysis of these parameters. The biological water parameters were not available. The data obtained were for the period from 2000 to 2003, 2011 to 2014, and 2016. A preliminary quality check of water quality data indicated that the sampling campaigns were either not covering all points within a single sampling campaign or in any one of the sampling years. Hence, there was a lack of continuity for some sampling points and water quality parameters. The selection of water quality parameters used in this study was based on the mostly measured and monitored parameters. The analysis of historical data for this work was based on the sampling depth of $0.5 \mathrm{~m}$ throughout because for each sampling point, at least a depth of $0.5 \mathrm{~m}$ below the water surface was sampled and analysed for all parameters used. This was in contrary to other depths below $0.5 \mathrm{~m}$ which was not consistency for all sampling points.

\section{Data analysis}

The temporal variation of water quality was done to assess the effect of time on pollution. This aimed to enable us to understand the trend of water quality pollution; if it is increasing, decreasing or remains unchanged with time. The statistical analysis tools were used to analyze the collected historical water quality data. Statistical software SPSS version 23.0 was employed to analyze physical and chemical water quality data for different statistics including Pearson correlation (looking for relationships), coefficient of determination and one-way Analysis of Variance (ANOVA). ANOVA was used to find out if there were statistically significant variation of water quality parameters between lake zones. The statistical significance level used for all tests was 0.05 for two-tailed tests. The Microsoft Excel tool was used for producing graphs like histograms and tables. The spatial variation of water quality for different parameters was undertaken using ArcGIS and QGIS software. Since the physical sampled water quality data did not cover the whole lake for the same sampling in a year, remote sensing techniques were used. Medium Resolution Imaging Spectrometer (MERIS), a sensor on board the polar-orbiting ENVISAT-1, with inbuilt algorithm and high spatial resolution suitable for a large water body like Lake Victoria, was used to analyze the spatial variation of Chrollophyl- $a$ and Total Suspended Matter (TSM). Tanzania Standards for the receiving water bodies (2008) and World Health Organization guidelines (2008) for drinking water were used for checking the compliance.

\section{The land use and land cover classification for 2000, 2010 and 2014}

To classify the land use and land cover, Landsat Thematic Mapper (TM) satellite images with $30 \mathrm{~m}$ resolution were acquired from United States Geological Survey (USGS) website (http://glovis.usgs.gov) for August 2000, August 2010 and August 2014. Images with a cloud cover of less than $10 \%$ were used. The choice of Landsat images for this analysis was based on its relatively high spatial resolution of $30 \mathrm{~m}$, which is good for land classification. Its temporal resolution of 15 days makes it suitable for land change detection overtime. Nine tiles covering the Lake Victoria Catchment Basin (LVCB) were glued together and the LVCB area was clipped out of it. 
The land classification used the maximum likelihood digital image classification using the supervised classification method. This type of classification normally uses the training data by means of estimating the means and variance of the classes, which are used to estimate probabilities, variance of the classes and also consider the variability of brightness values in each class. The classification is based on Bayesian probability theory. It is the most powerful classification method when accurate training data is provided and is the most widely used algorithm. In order to validate the classification output, ground control points were collected from different classes of land use and land cover at the study area using the Global Positioning System (GPS) and were used for validation of the 2015 classified map. ILWIS 3.7 software was used to analyse the image classification.

\section{RESULTS AND DISCUSSION}

The land use land cover changes within Tanzanian side of Lake Victoria basin

Land use land cover changes in a water basin play an important role in the environmental dynamics of the area (Schilling et al., 2008). Various human activities like agricultural activities, increase in population (which is attributed to increase in urbanisation and wastewater production), settlement construction and deforestation have significant effect to the water quality within that catchment (Tahiru et al., 2020). Figure and Error! Reference source not found. show the changes in land use and land cover for Lake Victoria on the Tanzanian side for the year 2000 to 2014 . The figures show the land use land cover changes that took place with regard to the bare soil, urban areas, wetlands, water bodies, farm land, forest, grassland, woodland and indigenous forest from 2000 to 2014.

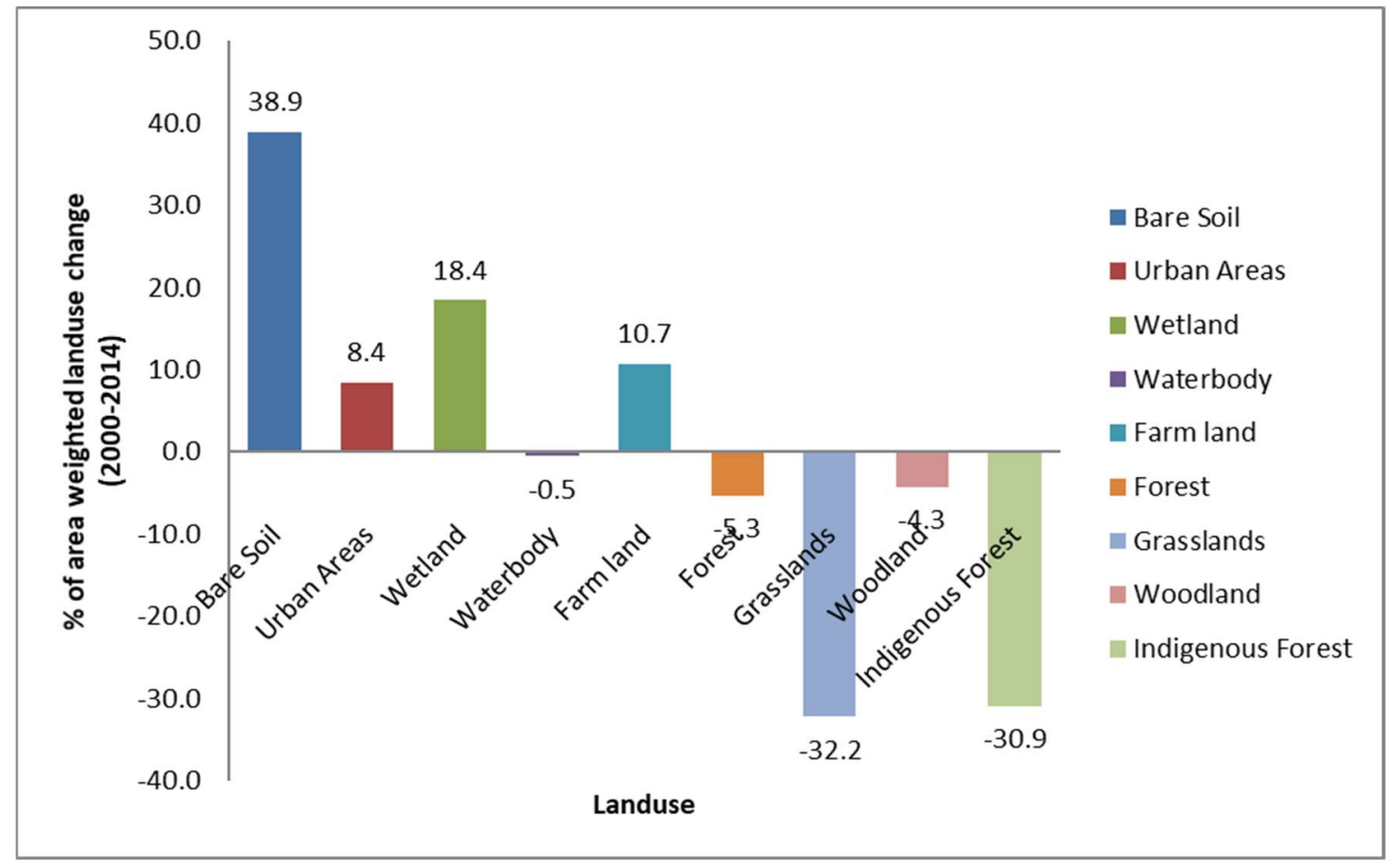

Figure 3: The area weighted land use change from year 2000 to 2014 in the $L V$ in the Tanzanian side 
Land Use Land Cover 2000

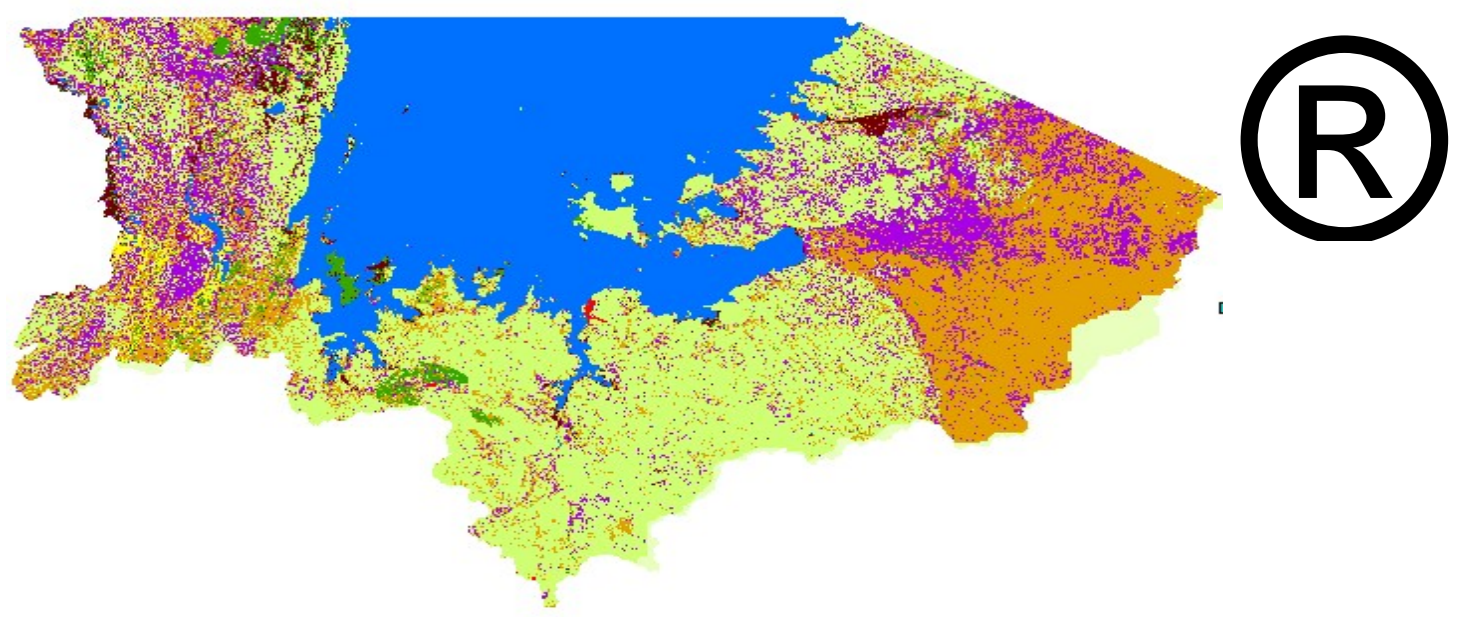

Land Use Land Cover 2010

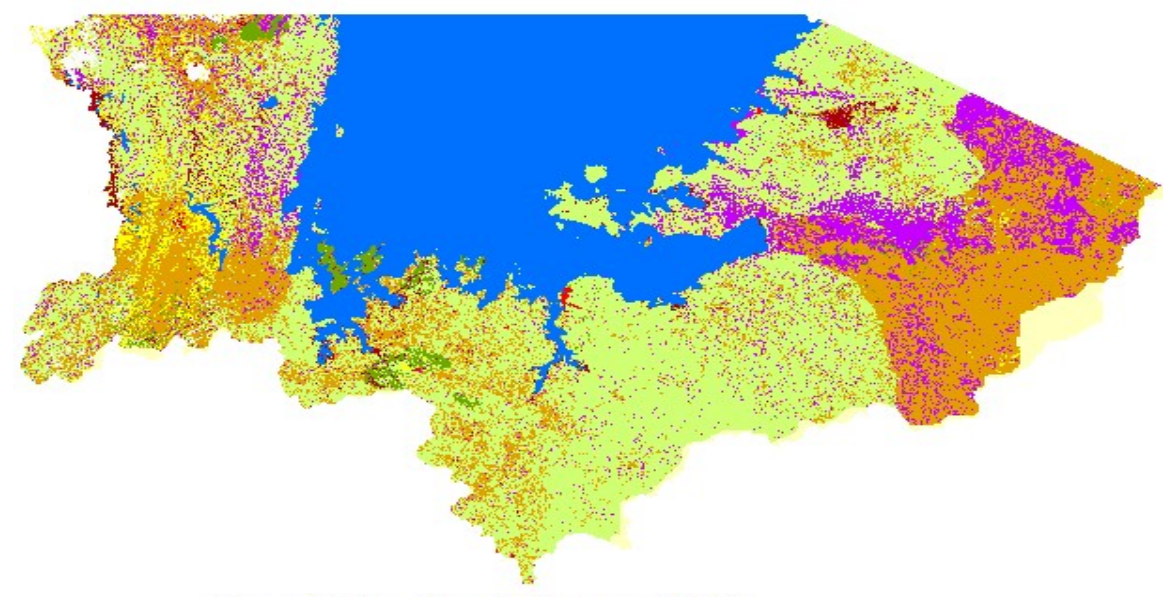

Land Use Land Cover 2014

Legend
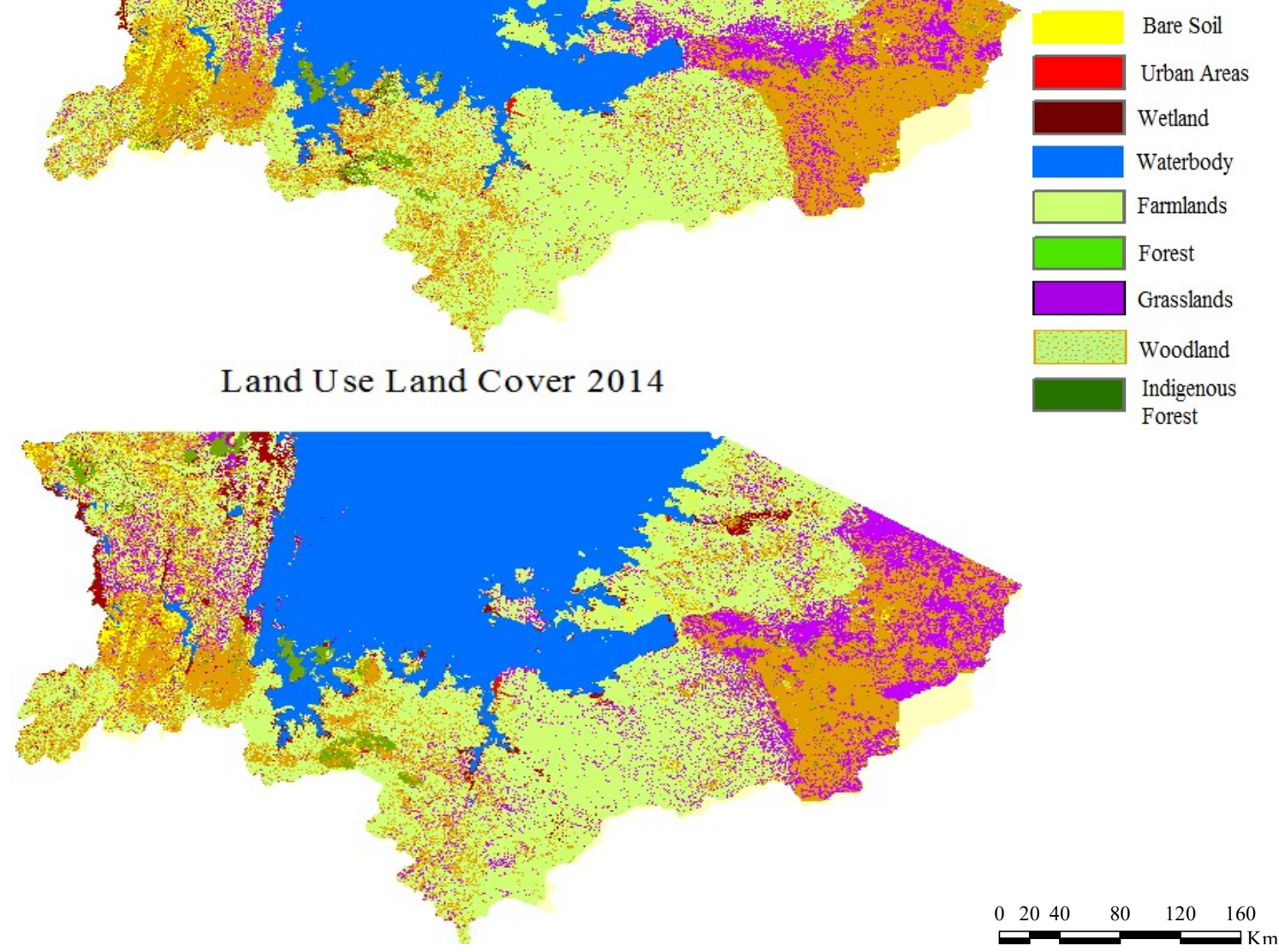

Figure 4: The land use land cover changes from 2000 to 2014 for the Tanzanian side of the Lake Victoria 
The bare soil was observed to increase by $38.9 \%$, urban areas were observed to increase by $8.4 \%$, farm land increased by $10.7 \%$, wetlands increased by $18.4 \%$ and water bodies increased by $0.5 \%$. On the other hand, forest area decreased by $5.3 \%$, grassland decreased by $32.2 \%$, woodland decreased by $4.3 \%$ and indigenous forest decreased by $30.9 \%$.

The land use land cover changes could be probably due to the increase in urban space, bare soil and farmland resulting in the decrease in grassland, woodland and indigenous forest, as these were cleared either to get an area for cultivation or land for different developments, while the forest, where cut down for firewood or for various activities (Schilling et al., 2008; Anhwange et al., 2012; Hua, 2017).The use of veld fires to clear land for cultivation could also be one of the causes of the decrease in grassland and woodland areas. These activities expose bare soil to erosion during the rainy season. The findings from this study correspond to the findings which were reported elsewhere (Schilling et al., 2008; Hua, 2017; Tahiru et al., 2020, Rather and Dar, 2020; Kibena et al., 2014) whereby it was observed that the changes in land use and land covers, especially the increase in settlements, bare soil and farming activities within the catchment, led to decreases in the water quality of the respective study areas.

\section{Variation of Water Quality Concentrations for Pelagic Zone}

Error! Reference source not found. below shows the results summary for water quality measurements of Lake Victoria from year 2000 to 2016. The measurements were done in the years 2000-2004, and then it was resumed again in the years 20112014 and 2016 by LVBWO. The one-way ANOVA was used for analysis.

Table 2: Summary of water quality for Lake Victoria from 2000 to 2016 for pelagic

zone

\begin{tabular}{|l|l|l|l|l|}
\hline Water quality parameter & No. of measurements & Min & Max & Mean \\
\hline Temperature $\left({ }^{\circ} \mathrm{C}\right)$ & 86.00 & 22.80 & 28.68 & 24.90 \\
\hline $\mathrm{pH}$ & 94.00 & 6.30 & 10.52 & 8.07 \\
\hline DO $(\mathrm{mg} / \mathrm{l})$ & 81.00 & 3.42 & 10.21 & 6.92 \\
\hline Nitrates $(\mathrm{mg} / \mathrm{l})$ & 105.00 & 1.00 & 447.00 & 32.20 \\
\hline Turbidity $(\mathrm{NTU})$ & 110.00 & 1.00 & 15.80 & 2.00 \\
\hline EC $(\mu \mathrm{S} / \mathrm{cm})$ & 90.00 & 59.20 & 155.44 & 96.05 \\
\hline Chlorophyll-a $(\mu \mathrm{g} / \mathrm{l})$ & 105.00 & 1.0 & 72.17 & 6.14 \\
\hline
\end{tabular}

\section{The temporal variation of $\mathrm{pH}$ values for pelagic stations}

Eighty-six sampling campaigns conducted from year 2000 to 2016 were used for the analysis. The minimum value of $\mathrm{pH}$ observed for the identified period was 6.3 , the maximum value of $\mathrm{pH}$ was 10.52 and the mean value for the same period was 8.07. Figure 0 below shows the variation of $\mathrm{pH}$ for pelagic stations in Lake Victoria.
From Figure 0, the analysis of variation of $\mathrm{pH}$ within time and points revealed that there was a variation of $\mathrm{pH}$ with time and points within the lake. The lowest levels of pH 6.3 and 6.8 were observed in year 2001 and 2002 respectively while the highest value of $\mathrm{pH} 10.52$ was observed in 2014.The analysis showed that the variation 
of $\mathrm{pH}$ between the points was not significant with $\mathrm{p}>0.05(\mathrm{p}=0.08)$. The weak positive correlation $\left(\mathrm{R}^{2}=0.26\right)$ of $\mathrm{pH}$ and DO pelagic zone of Lake Victoria corresponds to the positive correlation between $\mathrm{pH}$ and $\mathrm{DO}$ for lake Ilorion in Nigeria which was reported by (Araoye, 2009).

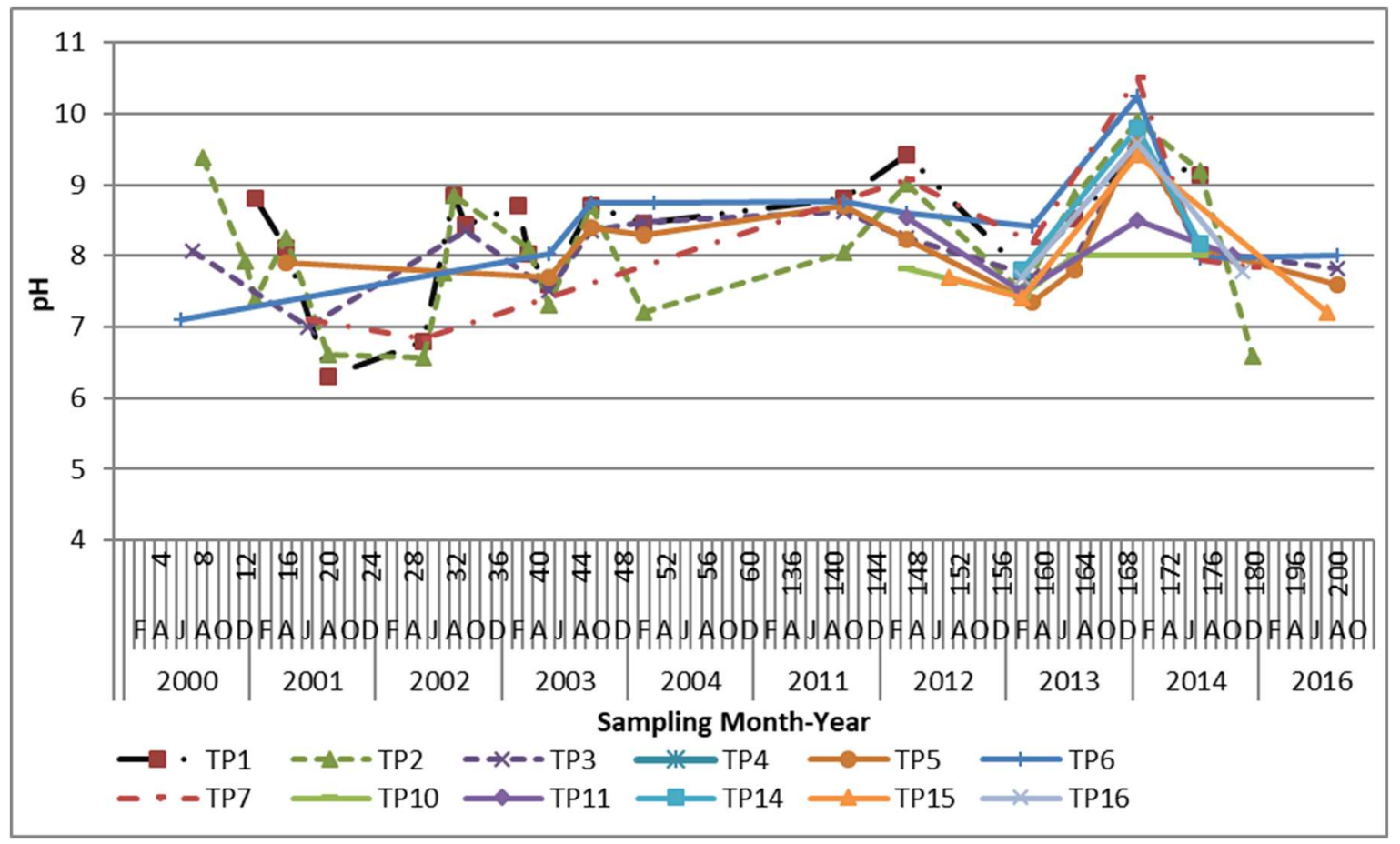

Figure 0: The temporal variation of $\mathrm{pH}$ values for pelagic zone

The temporal variation of DO concentration values for pelagic stations

The variation of DO concentration values for each point sampled was analyzed to identify the variation of the DO concentration of each point with time. The DO concentration values obtained were compared to the WHO guidelines and Tanzania Standards. The minimum value of DO concentration observed at the time of analysis was $3.42 \mathrm{mg} / \mathrm{l}$ and the maximum value was $10.21 \mathrm{mg} / \mathrm{l}$, with the average DO concentration value of $6.92 \mathrm{mg} / 1$. Error! Reference source not found. shows that there has been a variation of DO concentration values within the points with time.
It has been observed that for the period of 2000-2012, none of the points had a DO concentration values of less than $5 \mathrm{mg} / \mathrm{l}$, a minimum standard recommended by (WHO, 2010) as the allowable minimum standard for DO concentration values in a lake. For the period of March 2013, some points experienced DO oxygen of less than $5 \mathrm{mg} / \mathrm{l}$. The low experienced DO concentration values at this time can be attributed to the presence of high rainfall whereby storm water carrying waste from the catchment and urban areas were discharged to the lake (Scheren et al., 2000). The discharge of the waste resulted to decomposition of waste and hence more oxygen was used to decompose the waste (Scheren et al., 2000). 


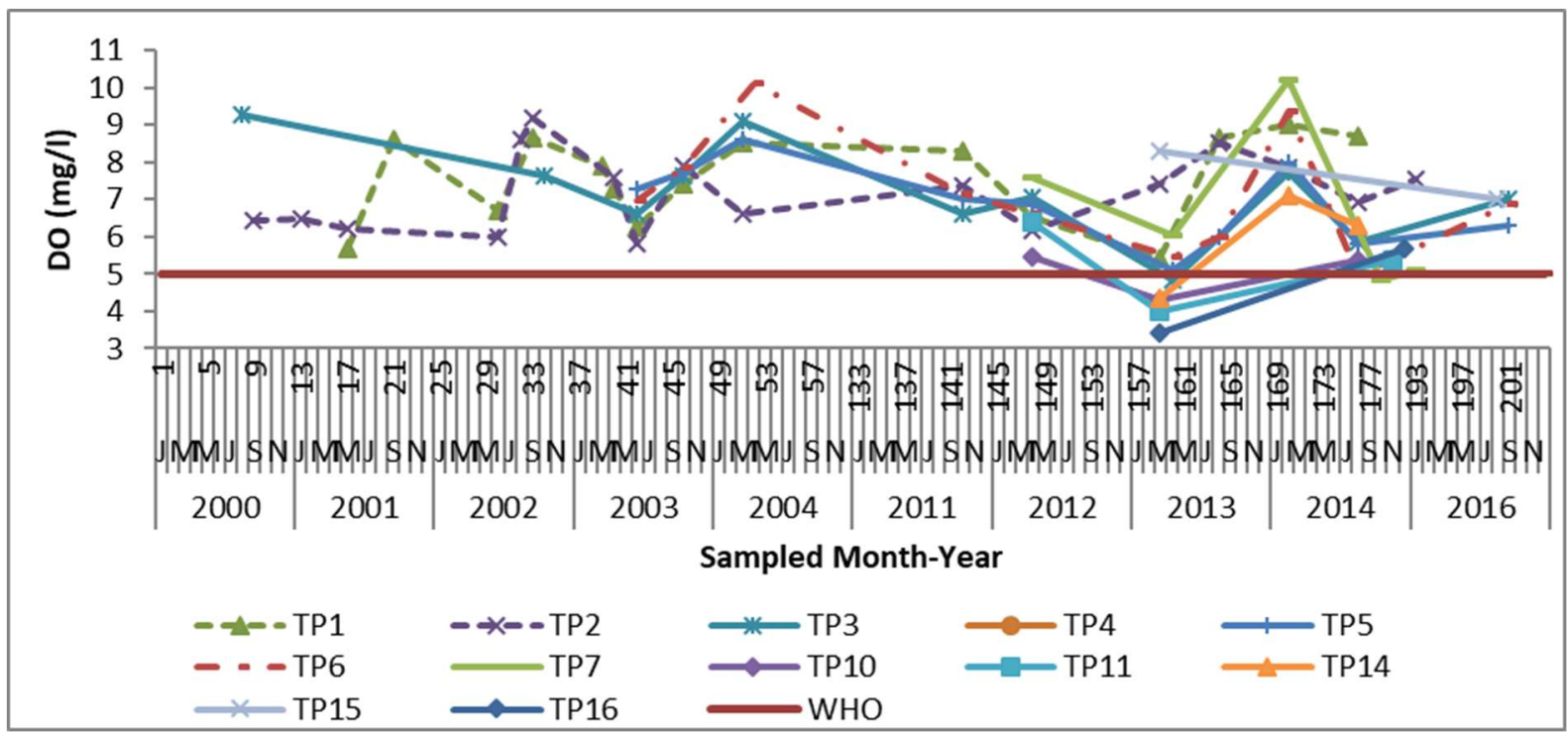

\section{Figure 6: The temporal variation of DO concentration values for pelagic zone for the} period of 2000 to 2016

\section{The temporal variation of Nitrates for concentration values pelagic stations}

The variation of nitrates for concentration valuesfor pelagic zone was conducted. The analysis was from the years 2000-2016. The $\mathrm{NO}_{3}$ concentration values obtained after each sampling campaign for every month and year when the sampling was done was used for the analysis. It was observed that for the specified period of time the minimum value of nitrates was found to be $1 \mathrm{mg} / \mathrm{l}$ and the maximum value was observed to be $447 \mathrm{mg} / \mathrm{l}$, with a mean value of $32.2 \mathrm{mg} / 1$.

It was observed that the values of nitrates concentration varied within the points for the pelagic stations. Njuru, (2012) observed that the values of nitrates concentration values were high when the monitoring campaign for the lake started in year 20002003. The values of nitrates concentration were observed to be low in year 2011-2012. This can be attributed to the monitoring campaign which was conducted by LVEMP together with other stakeholders around the lake aiming to reduce the water hyacinth which are mostly as a result of presence of nitrates and phosphates. Repeated Analysis of variance showed that there was no significant variation of nitrates concentration between the sampling points as $p>0.05$. The sharp increase in nitrates observed in Figure 2can be attributed to the time of sampling campaign. Similar findings were observed by (Boström, 1981). The water quality sampling campaigning for year 2013-2016 was carried out during the rainy season. The period of March to May is marked by high rainfall in the area. As a result, the values of Nitrates were observed to be higher than the values of sampling which was conducted in the dry season or less rainfall. This shows that most of the runoff which goes to the lake was likely to have high values of nitrates (Scheren et al., 2000). 


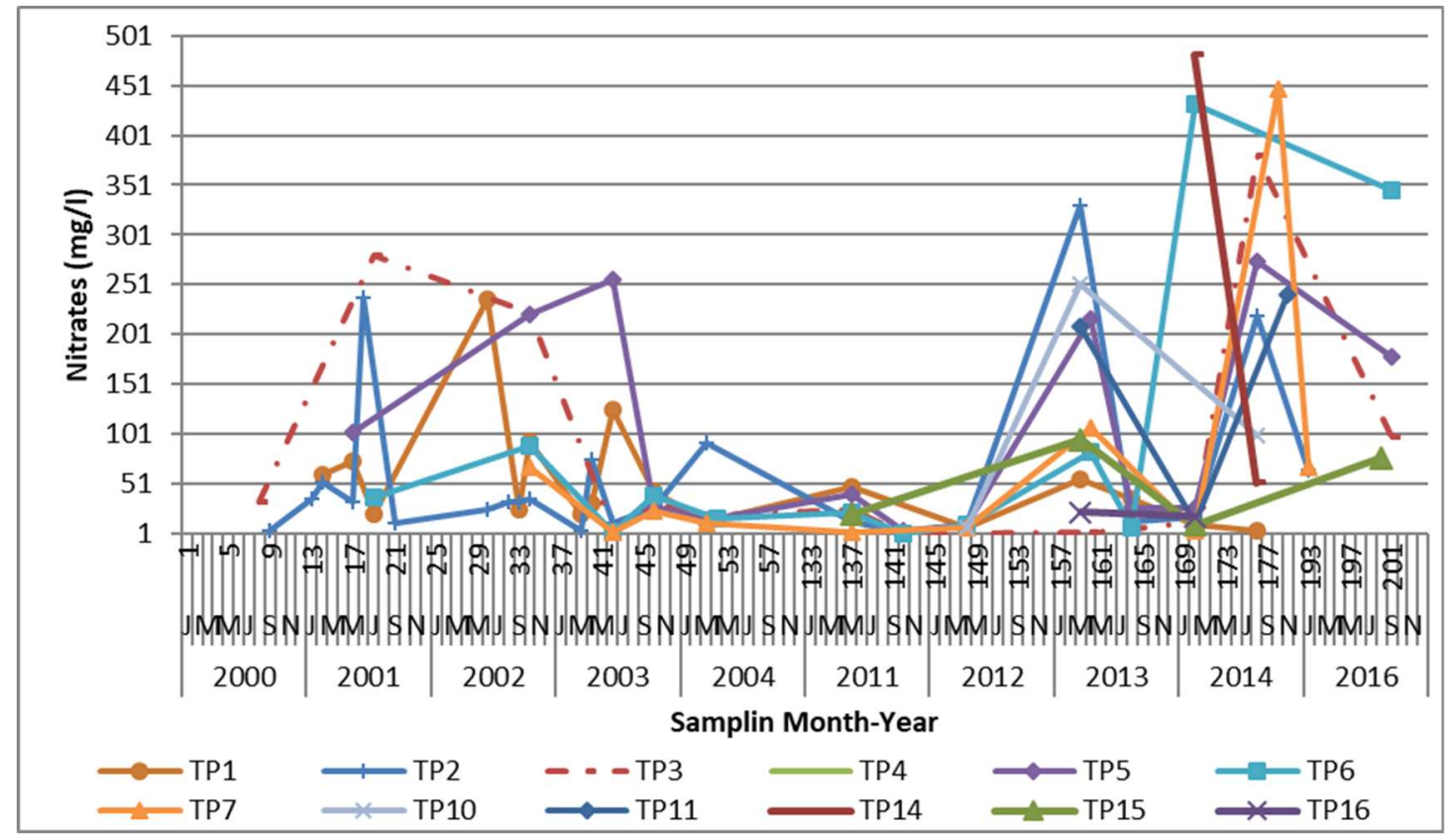

Figure 2: The temporal variation of Nitrates concentration values for pelagic stations

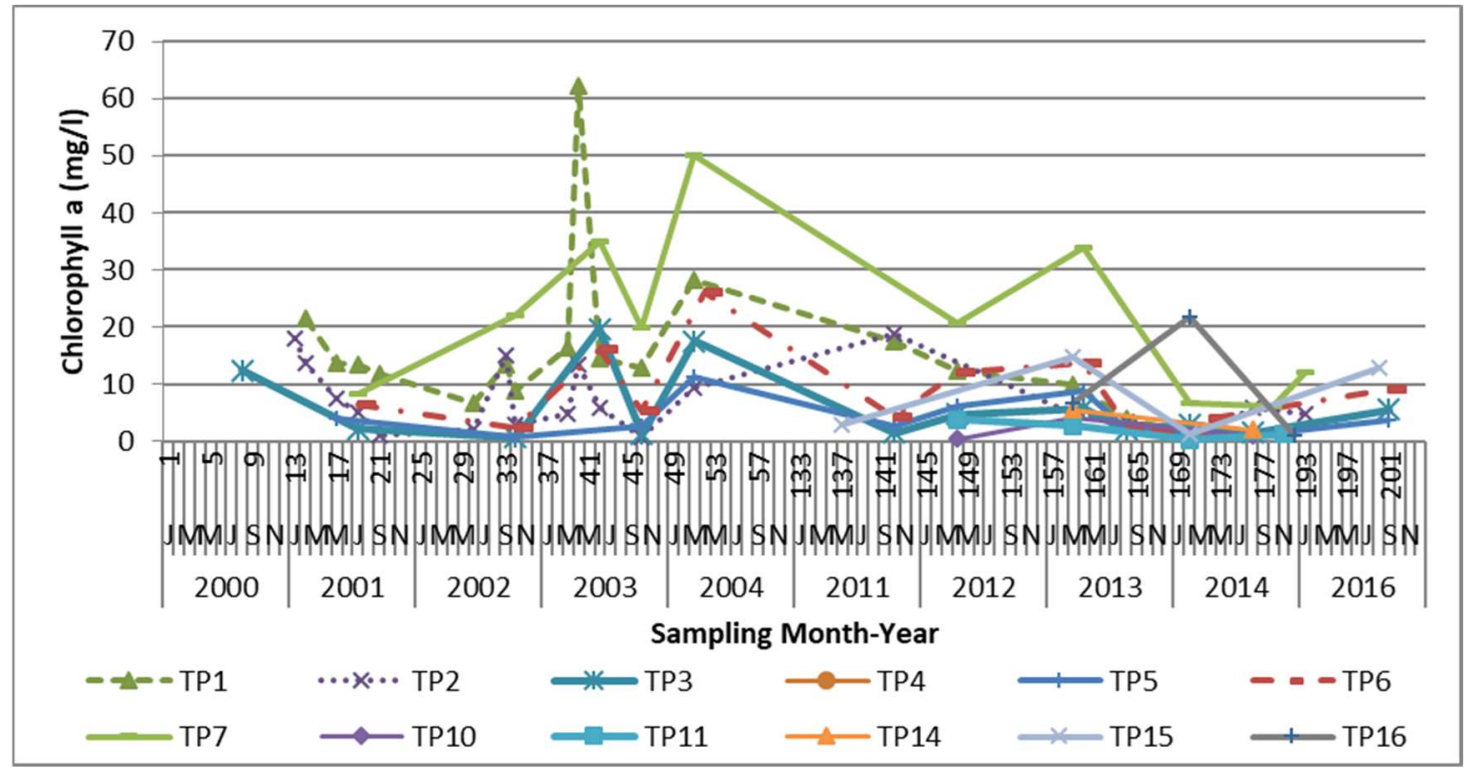

Figure 3: Temporal variation of Chlorophyll- $a$ values for pelagic stations

Temporal variation of Chlorophyll-a values for pelagic stations

Chlorophyll- $a$ was observed to vary with time and seasons as shown in Figure 3. The Chlorophyll- $a$ concentration values were observed to decrease from $20.8 \mu \mathrm{g} / 1$ in 2004 to $11.3 \mu \mathrm{g} / 1$ in 2016 . It was observed that the Chlorophyll- $a$ concentration was higher during the rainy seasons than the dry seasons. This complies with the study by
Wondie et al., (2007), who observed that the Chlorophyll- $a$ concentration varies seasonally in lake Tana of Ethiopia. The increase in Chlorophyll- $a$ concentration during rainy season can be attributed to the increase in nitrates and phosphates which are carried by runoff and discharged to the lake. It was also observed that there was a negligible relationship between Chlorophyll- $a$ concentration and $\mathrm{pH}$ values, the polynomial relationship gave the 
coefficient of $\mathrm{R}^{2}=0.16$ and $p>0.05$ for pelagic zone. This was contrary to what was reported by Zang et al., (2011), who observed a positive correlation between Chlorophyll- $a$ and $\mathrm{pH}$. This could probably be due to the fact that the existence of $\mathrm{pH}$ could be contributed by factors other than Chlorophyll-a (Wondie et al., 2007).

\section{The temporal variation of Turbidity values for pelagic stations}

Analysis of variation of turbidity values for pelagic points in Lake Victoria was done as shown in Error! Reference source not found.. The minimum value of turbidity for the study period was observed to be 1 NTU and maximum value was 15.8 NTU, with a mean value of 2 NTU. Turbidity values were observed to vary for the pelagic stations. The variation of turbidity values within the lake were observed to be low. Only one sampling point, TP2, was observed to have a value of turbidity higher than 5 NTU, which is recommended by WHO. The same point was also observed to have a higher value than the allowable standard in year 2011. Most of the sampling points were observed to have the values of turbidity within the allowable limit by WHO, except in the years 2012 and 2014, where the turbidity values were recorded to be higher than the recommended limit of 5 NTU. This can be attributed to a runoff which was introduced to the lake during the sampling campaign as the month of March to May is the season of high rainfall in the area (Scheren et al., 2000). Hence all runoff from the catchment is discharged to the lake (Scheren et al., 2000).

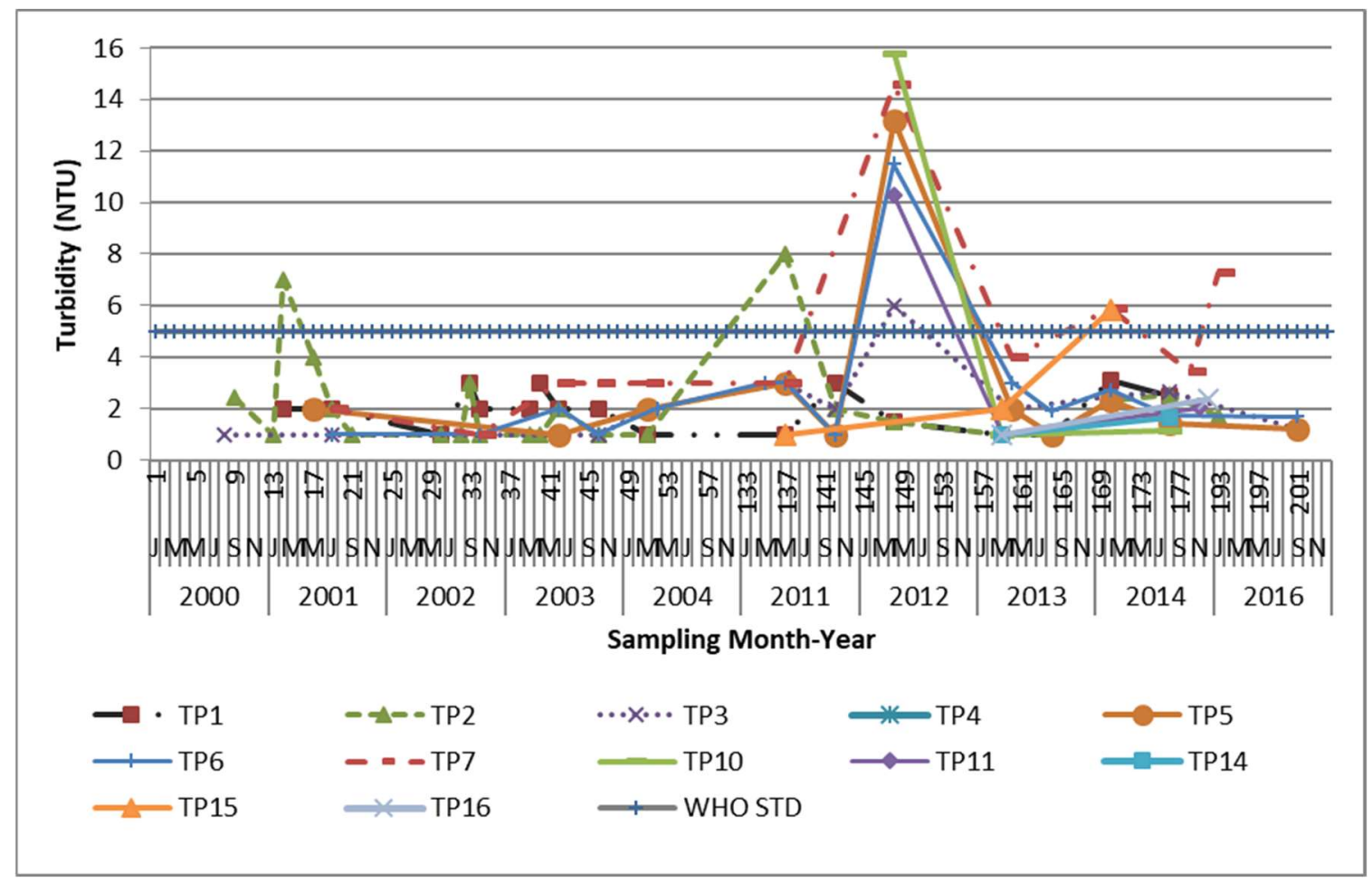

Figure 4: Temporal variation of turbidity values for pelagic stations

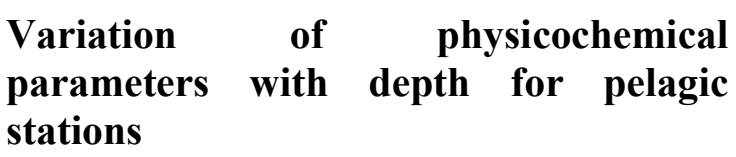

Analysis of the variation of physical parameters with depth was also undertaken. The analysis was undertaken for stations TP1, TP2 TP3, TP4, TP5, TP6 and TP7 
since they are the most sampled points. Figure 5 presents the analysis results of physicochemical parameters which were conducted for pelagic stations. The measurement was undertaken from the water surface to the bottom of the lake ( 80 m deep).

The physicochemical parameters of the lake (DO, Temperature, $\mathrm{pH}$ and $\mathrm{EC}$ ) for pelagic zones were observed to vary with depth as shown in Figure 5. It was observed that DO, Temperature and $\mathrm{pH}$ were decreasing towards the bottom of the lake. Electrical conductivity was observed to increase with an increase in depth. The same trend of decrease in physical parameter with increase in depth of the lake was observed by Pukate and Rim-Rukeh, (2008). DO was observed to decrease from $8.59 \mathrm{mg} / 1$ at the surface of the lake to $1.8 \mathrm{mg} / \mathrm{l}$ at a depth of $80 \mathrm{~m}$. The decrease in DO at the bottom of the lake is supported by observed increase in EC which implies that more saltiness is found at the bottom of lake which reduces the solubility of the dissolved gases (Sharma and Tiwari, 2018). Temperature decreased from $25{ }^{\circ} \mathrm{C}$ from the surface of the lake to $24{ }^{\circ} \mathrm{C}$ at a depth of $80 \mathrm{~m}$. The $\mathrm{pH}$ of the lake was observed to decrease with depth from 8 to $7.4 \mathrm{~m}$. The value of electrical conductivity was observed to be slightly constant ranging from 87.4-88.9 $\mu \mathrm{S} / \mathrm{cm}$ up to a depth of $30 \mathrm{~m}$. Beyond $30 \mathrm{~m}$, the value of EC was observed to increase to $106.3 \mu \mathrm{S} / \mathrm{cm}$ at a depth of $80 \mathrm{~m}$.
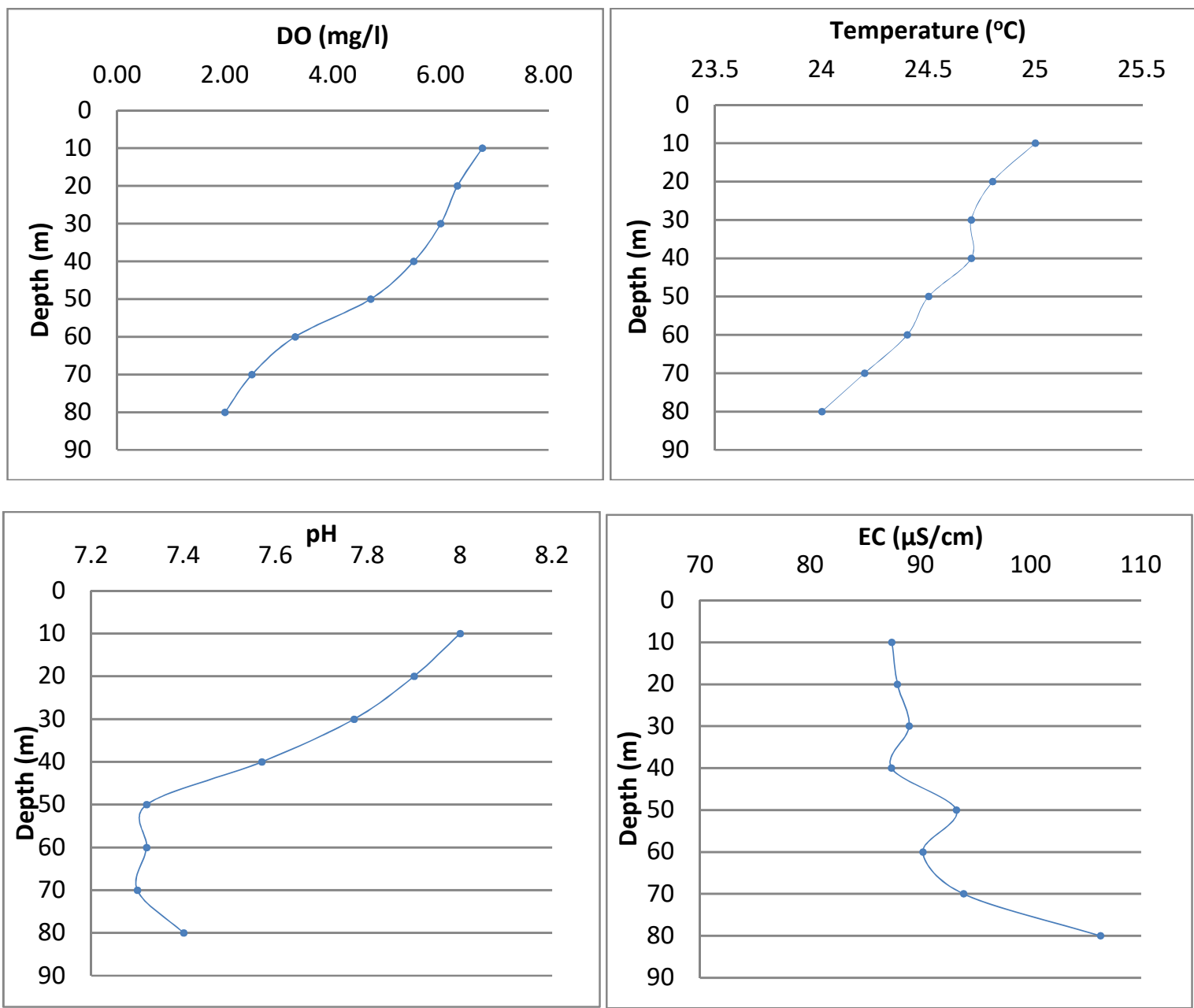

Figure 5: Variation of physicochemical parameters with depth for pelagic stations 
This could be due to the fact that the lake acts as a repository for most wastes which are introduced to it, therefore the settled waste may have more impact on the bottom of the lake where it settles (Sharma and Tiwari, 2018). Hence more solute can be found at the bottom of the lake than at the top (Sharma and Tiwari 2018).

\section{The Variation of Water Quality Concentrations for Littoral Zone}

Error! Reference source not found. below shows the statistics results summary for water quality measurements of Lake Victoria from the year 2000 to 2016 for littoral zone. The measurements were done in the year 2000 and then it was resumed again in the years 2011-2014 and 2016. Six sampling points were used, sampling and analysis was undertaken by LVEMP. The monthly values obtained for each year of the sampling campaign were used for analysis of each parameter.

Table 3: Summary of water quality for Lake Victoria from 2000 to 2016 for littoral zone

\begin{tabular}{|l|c|c|c|c|}
\hline Water quality parameter & No. measurements & Min & Max & Mean \\
\hline Temperature $\left({ }^{\circ} \mathrm{C}\right)$ & 35.00 & 22.30 & 26.80 & 24.90 \\
\hline $\mathrm{pH}$ & 37.00 & 6.47 & 10.16 & 9.06 \\
\hline $\mathrm{DO}(\mathrm{mg} / \mathrm{l})$ & 38.00 & 3.99 & 8.60 & 6.67 \\
\hline Nitrates $(\mu \mathrm{g} / \mathrm{l})$ & 41.00 & 4.00 & 590.16 & 28.00 \\
\hline Turbidity $(\mathrm{NTU})$ & 38.00 & 1.30 & 75.00 & 6.00 \\
\hline EC $(\mu \mathrm{S} / \mathrm{cm})$ & 32.00 & 8.35 & 189.00 & 113.20 \\
\hline Chlorophyll- $a(\mu \mathrm{g} / \mathrm{l})$ & 37.00 & 1.79 & 64.99 & 12.37 \\
\hline
\end{tabular}

Temporal variation of $\mathrm{pH}$ values for littoral stations

The monthly values of $\mathrm{pH}$ obtained for each sampling campaign for each year were used to analyze the variation of $\mathrm{pH}$ values with time. Error! Reference source not found. below shows the variation of $\mathrm{pH}$ in Lake Victoria for littoral stations.
Six sampling points, TL002, TL230, TL231, TL232, TL233 and TL 234 were used. These sampling points were the only sampling points which were sampled for at least more than three years in all sampling campaign.

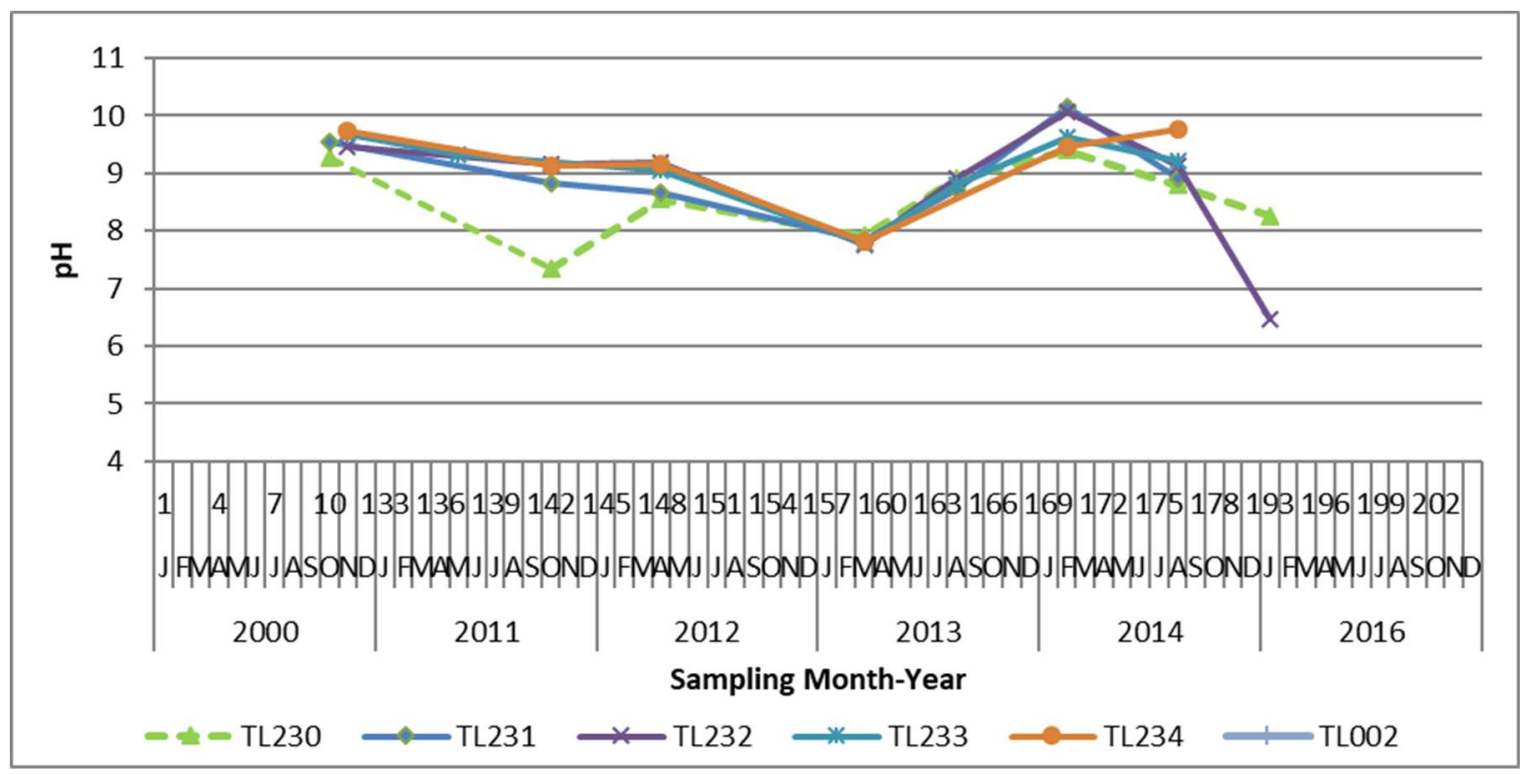


Figure 6: Variation of $\mathbf{p H}$ values for littoral zone

From Error! Reference source not found., it is observed that the $\mathrm{pH}$ values were varying within the sampling points. But the variation of $\mathrm{pH}$ of Lake Victoria waters was still within the acceptable range of $\mathrm{pH} 6.5$ 8.5 recommended by WHO for surface water. According to Zang et al., (2011), there is a relationship between the $\mathrm{pH}$ and $\mathrm{DO}$ in water body whereby increase in $\mathrm{pH}$ results in increase in $\mathrm{DO}$ and decrease in $\mathrm{pH}$ results in decrease in DO. The relationship was tested and it was observed that any increase in $\mathrm{pH}$ resulted to an increase in DO and the vice versa. This is due to the reduction-oxidation reaction which exists in the water body which relates to its acidity. Tadesse et al., (2004) reported similar observations in their work studying the seasonal and diurnal variations of temperature, $\mathrm{pH}$ and dissolved oxygen in advanced integrated wastewater pond system treating tannery effluent.

\section{Temporal variation of DO concentration values for littoral stations}

The variation of DO concentration values for littoral zone was analysed. DO concentration values for littoral zone ranged from 3.99-8.6 mg/1 for the period of the study. Variations of DO were observed as shown in Figure 7. It was observed that most of the sampling points from the study period had the value of DO greater than the WHO minimum recommended value of DO for surface water body. Nevertheless, it was observed that one sampling point had the value of DO concentration less than $5 \mathrm{mg} / \mathrm{l}$ as recommended by WHO in year 2013 and 2014. The variation within the sampling points was statistically not significant with $\mathrm{p}>0.71$.

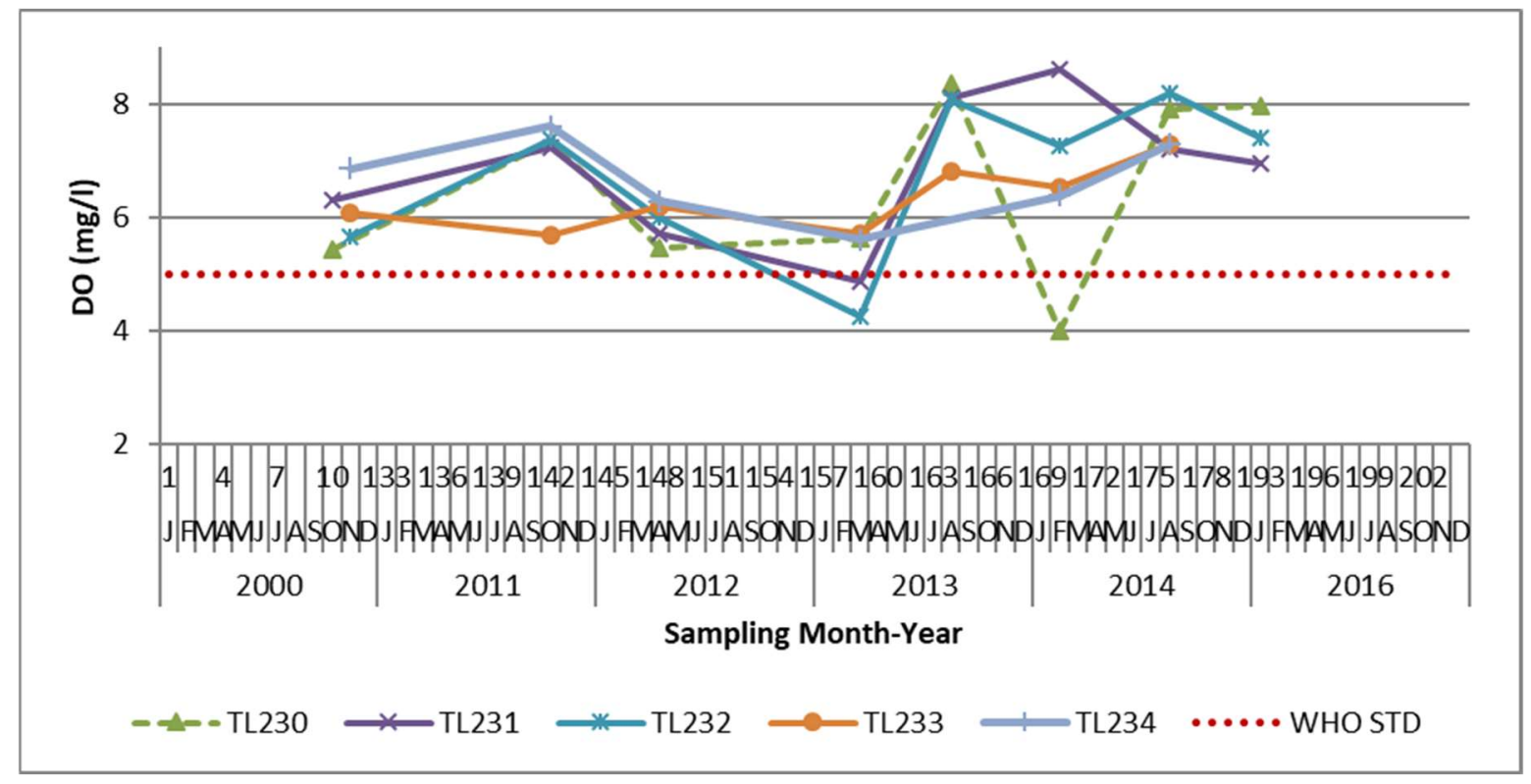

Figure 7: Spatial Temporal variation of DO concentration values for littoral zone

\section{Temporal variation of Nitrates concentration values for littoral stations}

The analysis of variation of nitrate concentration values for littoral zone was undertaken and analyzed. The sampling was done in year 2000 and resumed again in year 2011 to 2014 and 2016. The analysis results are presented in Figure 13. It was observed that for the specified period of time, the minimum value of nitrates concentration was observed to be $4 \mathrm{mg} / \mathrm{l}$ 
and the maximum value was observed to be

$590.16 \mathrm{mg} / \mathrm{l}$, with a mean value of $28 \mathrm{mg} / \mathrm{l}$.

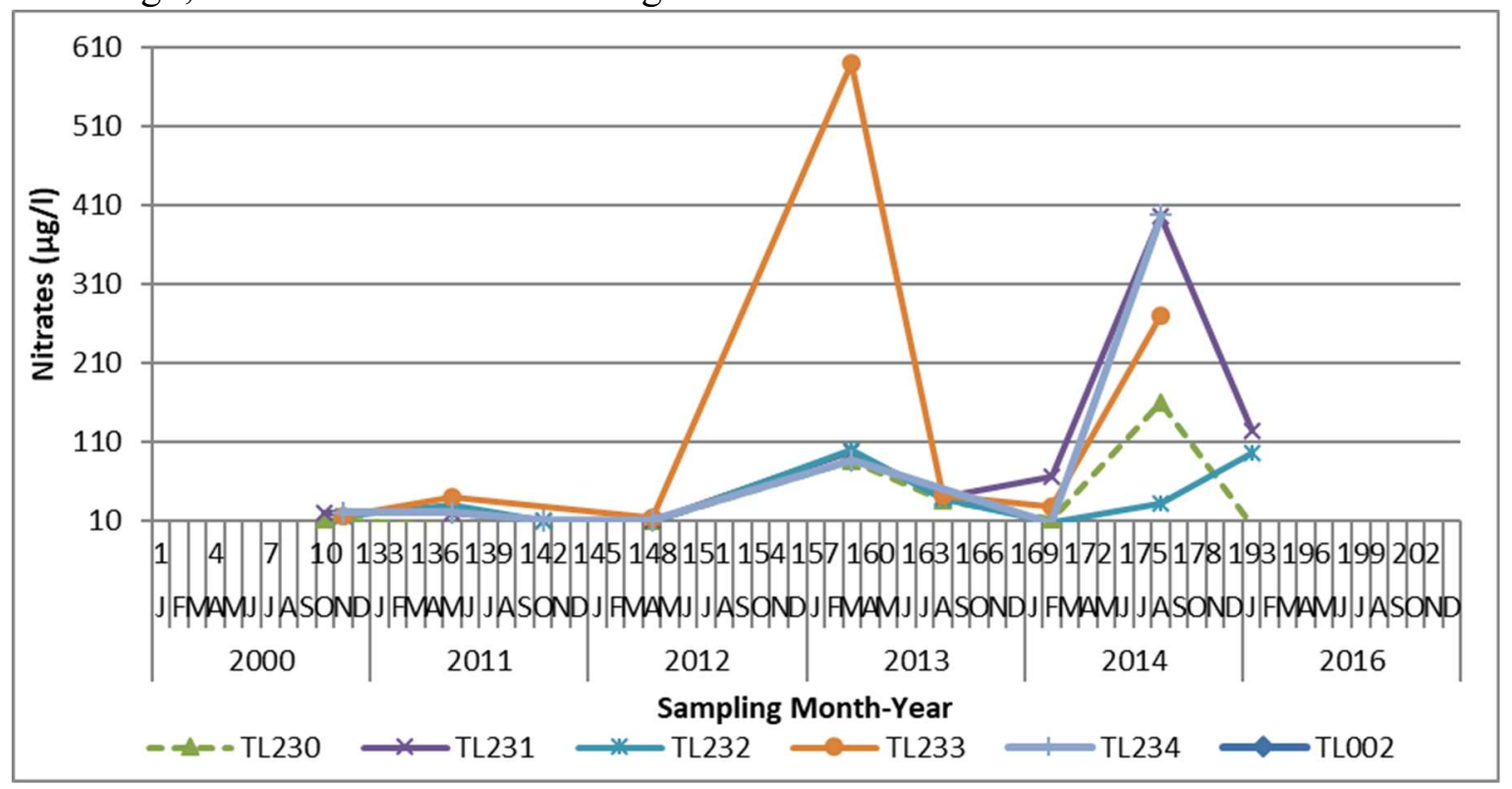

Figure 8: Variation of nitrates concentration values for littoral stations

Further, it was observed that the value of nitrates concentration were almost constant with the range of $10-110 \mathrm{mg} / \mathrm{l}$ throughout except for year 2013 and 2014 were the value of nitrates were observed to be high $510.16 \mathrm{mg} / 1$ and $398 \mathrm{mg} / \mathrm{l}$ respectively. The sharp increase in nitrates observed in Error! Reference source not found. can be attributed to the time of sampling campaign, the sampling for year 2013 and 2014 done during the rainy season, the period of March to May is the season of high rainfall in the area.

\section{Temporal variation of Chlorophyll-a values for littoral stations}

Although for littoral zones Chlorophyll- $a$ measurement was done from year 2011 to 2016, it was also observed that Chlorophyll- $a$ was varying with time and seasons as shown in Error! Reference source not found.. The Chlorophyll- $a$ concentration was observed to be higher in littoral zones compared to pelagic zones for the measurements which were done in same month for the same year. Chlorophyll- $a$ concentration was observed to be high in concentration for the measurements which were taken in rainy seasons (March-May) than those which were taken in dry season (June-September). The high concentration of Chlorophyll- $a$ observed in the year 2013 was due to high rainfall which occurred in March 2013.This could have attributed to the increase in concentration as more nutrients from the environment were discharged to the lake. There was a negligible relationship between Chlorophyll- $a$ and $\mathrm{pH}$, the polynomial relationship gave the coefficient of $\mathrm{R}^{2}=$ 0.23 and $p>0.05$ for the littoral zone. This was in contrary to what was reported by Zang et al., (2011) who observed a positive correlation between Chlorophyll- $a$ and $\mathrm{pH}$. 


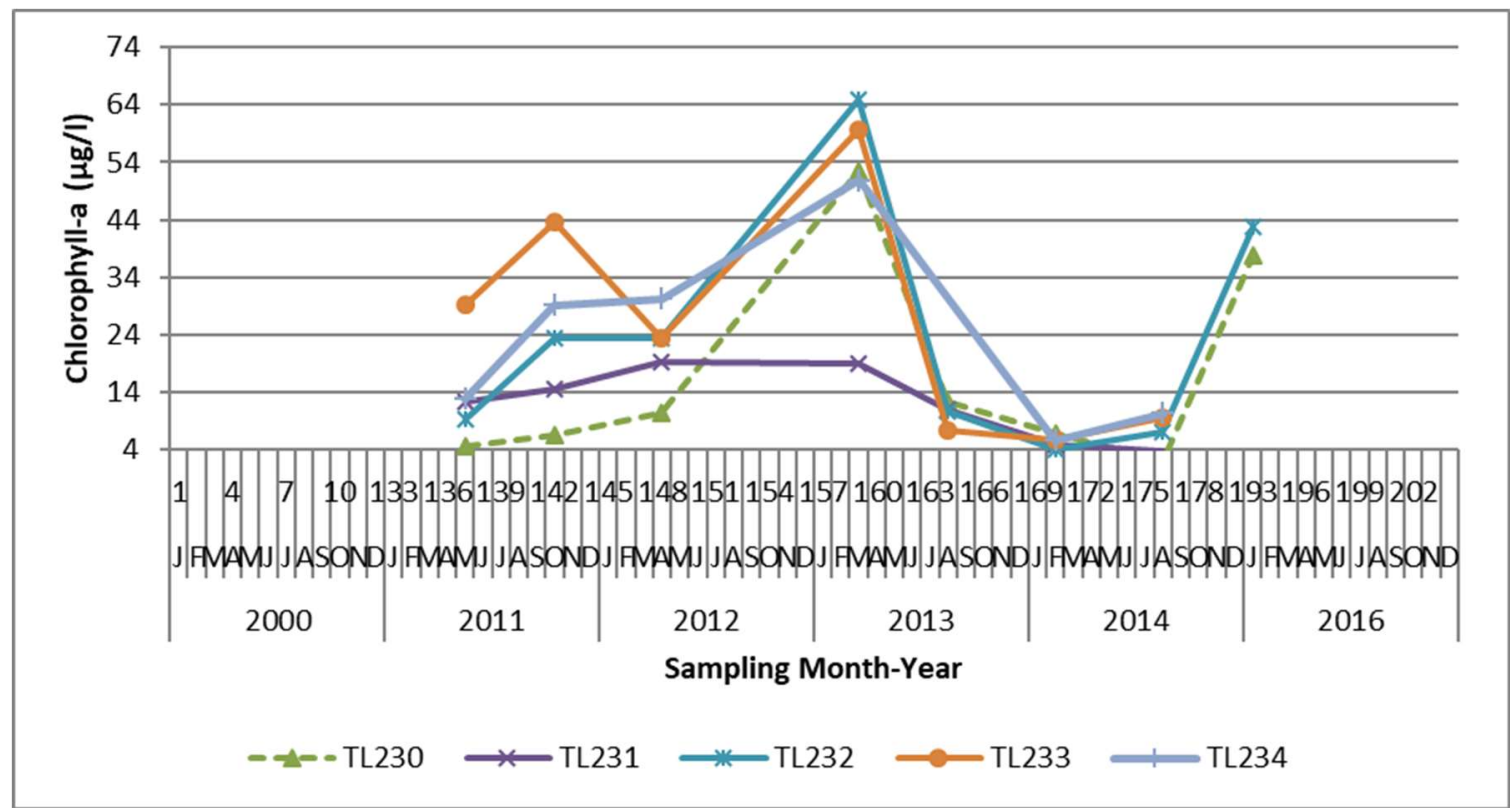

Figure 9: Variation of Chlorophyll- $a$ values for littoral stations

\section{Variation of physiochemical parameters with depth for littoral stations}

Analysis of the variation of physical parameters with depth for littoral stations was also carried out. The analysis was done for averages of stations TL230, TL231, TL232, TL233 and TL235 as they are the most sampled points in littoral zone. Error! Reference source not found. presents the analysis of physical parameters which were observed for littoral stations. The analyzed parameters were dissolved oxygen, temperature, $\mathrm{pH}$ and electrical conductivity.

The observed variation of physical conditions for littoral stations was similar to that of pelagic stations; they were found to be decreasing towards the bottom of the lake as shown in Error! Reference source not found.. There was a significant correlation between the value of physical parameters and the depth of

sampling except for electrical conductivity. The physicochemical parameters were observed to decrease with an increase with depth, but EC was observed not to obey the same trend. This could be due to suspension of dissolved particles in water.
It was observed that the relationship between temperature and depth in the lake

for the littoral zone was positively correlated with coefficient of $\mathrm{R}^{2}=0.6$ at $p<0.03$. A strong positive correlation was observed between DO and temperature with coefficient of $\mathrm{R}^{2}=0.78$ and $\mathrm{p}<0.01$. DO for the littoral zone. It was observed to be higher on the surface compared to what was observed on the pelagic zone. This could be due to the presence of more phytoplankton, which releases oxygen during the photosynthesis process than those found in pelagic zone. A similar observation was reported by Pukate and Rim-Rukeh (2008) $\mathrm{pH}$ and temperature were observed to have a strong correlation with coefficient of $\mathrm{R}^{2}=$ 0.95 and $\mathrm{p}<0.01$.

The correlation between electrical conductivity and depth for the littoral zone was observed to be weak with coefficient $\mathrm{R}^{2}$ $=0.37$ and $p>0.05$. Therefore, it can also be concluded that the observed trend of EC variation might be due to the suspension of dissolved and suspended solids in water due to mixing up of the water at the littoral zone. Dissolved solids and suspended solids are reported to increase the value of EC (Butler and Ford, 2018). 

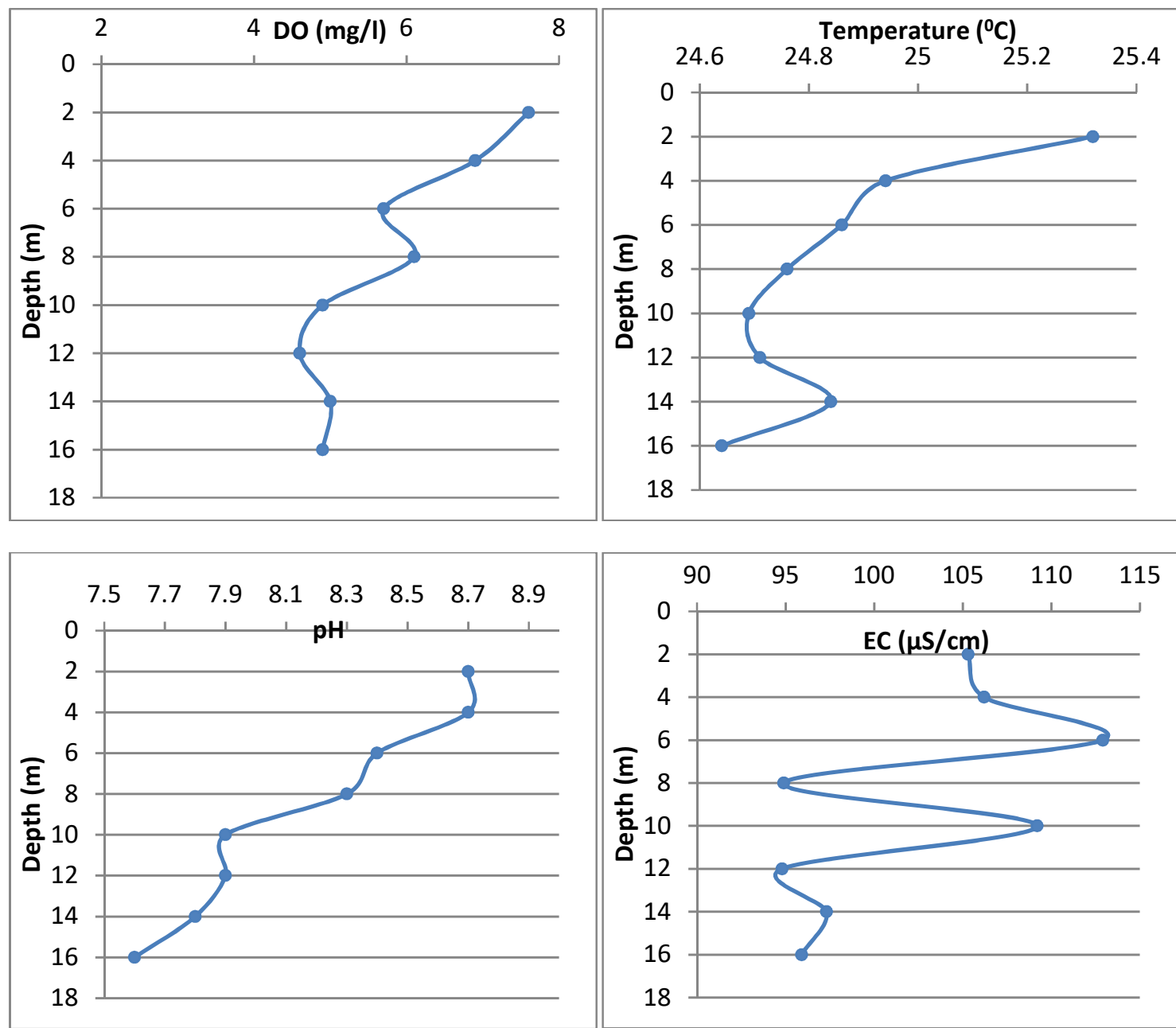

Figure 10: Variation of physiochemical parameters with depth for littoral stations

The correlation between electrical conductivity and depth for the littoral zone was observed to be weak with coefficient $\mathrm{R}^{2}$ $=0.37$ and $\mathrm{p}>0.05$. Therefore, it can also be concluded that the observed trend of EC variation might be due to the suspension of dissolved and suspended solids in water due to mixing up of the water at the littoral zone. Dissolved solids and suspended solids are reported to increase the value of EC (Butler and Ford, 2018).

\section{Variation of Chlorophyll a and Total Suspended Matter}

Spatial analysis of water quality was done for the whole lake. The analysis results is shown in Error! Reference source not found. and Figure 12. From Error! Reference source not found. and Figure 12, it can be observed that the concentration of Chlorophyll- $a$ and

Total Suspended Matter (TSM) of the lake has been increasing with time especially on the southern part, south east and south west of the lake. In 2003, the minimum concentration of Chlorophyll- $a$ in the lake was observed to be $0.045 \mathrm{~g} / \mathrm{m}^{3}$ while the maximum concentration was $41.26 \mathrm{~g} / \mathrm{m}^{3}$. In 2011, the minimum concentration of Chlorophyll- $a$ in the lake was observed to be $0.053 \mathrm{~g} / \mathrm{m}^{3}$ while the maximum concentration was $41.62 \mathrm{~g} / \mathrm{m}^{3}$.

The same areas were observed to have more concentration of TSM compared to other 
areas. In 2003, the minimum concentration of TSM in the lake was observed to be $0.026 \mathrm{~g} / \mathrm{m}^{3}$ while the maximum value was $39.98 \mathrm{~g} / \mathrm{m}^{3}$. In year 2011 , the minimum value of TSM in the lake was observed to be $0.04 \mathrm{~g} / \mathrm{m}^{3}$ while the maximum value was $52.18 \mathrm{~g} / \mathrm{m}^{3}$. The increase in concentration of Chlorophyll- $a$ and total suspended

\section{Chlorophylla (August 2003)}

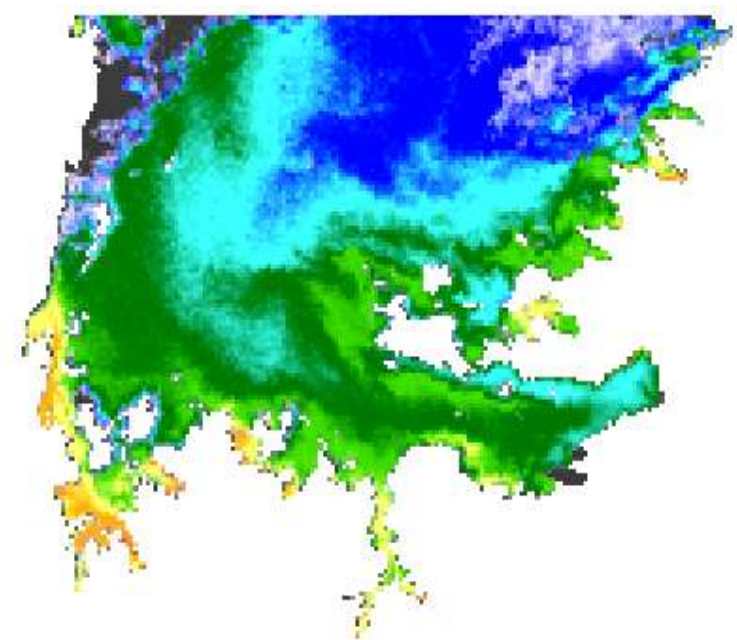

Chlorophylla (August 2009)
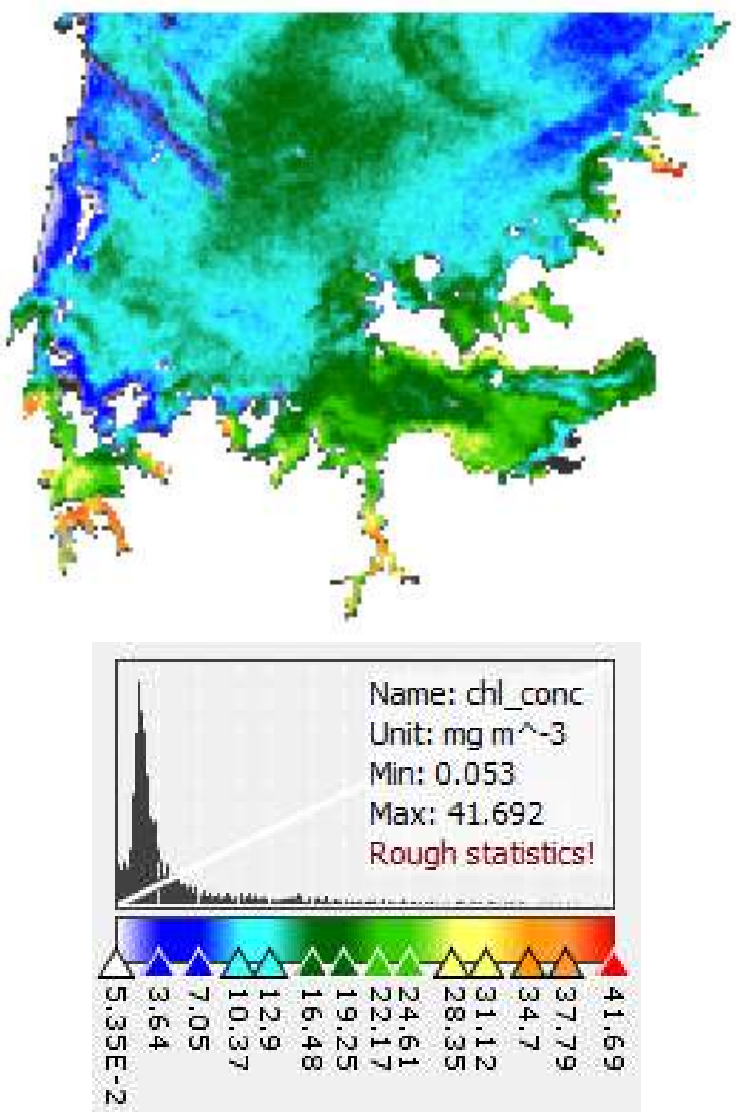

matter can be attributed to the increase in anthropogenic activities around the lake. The identified areas are subjected to pollution due to the presence of the rivers from the catchment which discharge water to the lakes through the identified areas.

\section{Chlorophylla (August 2006)}

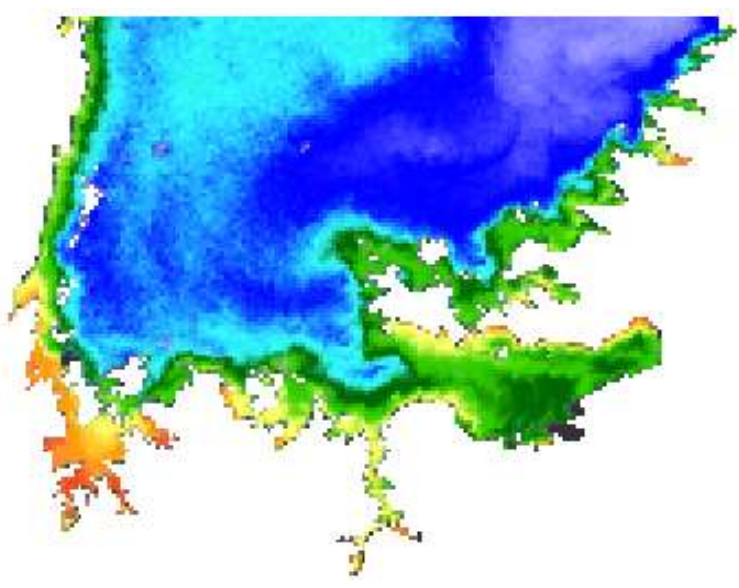

Chlorophylla (August 2011)

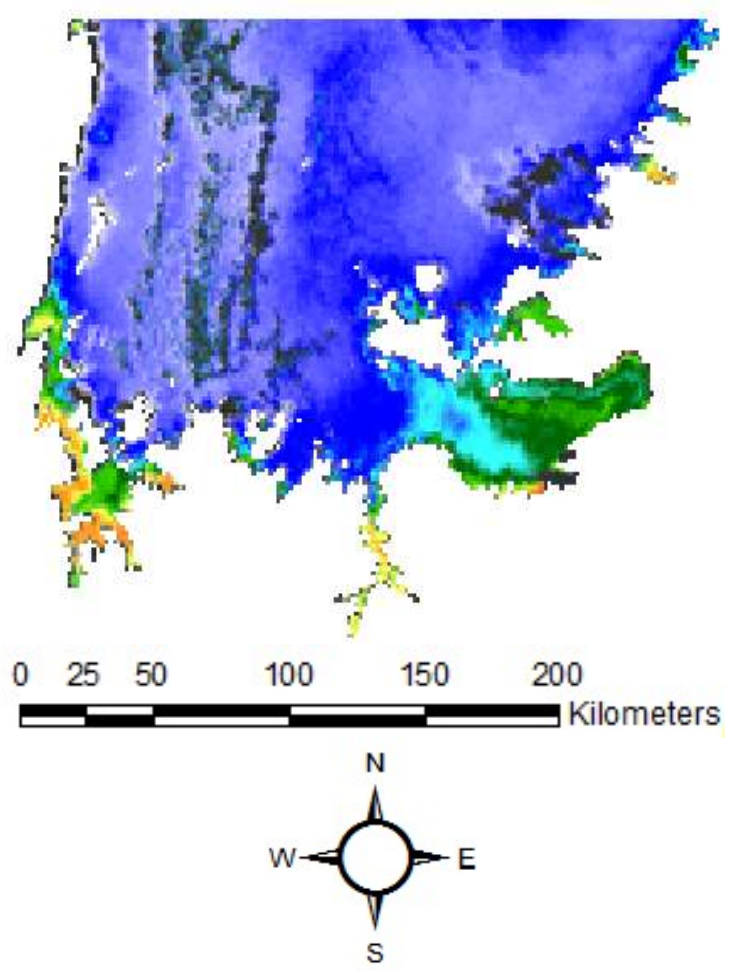


Figure 11: Spatial temporal variation of Chlorophyll- $a$ in a lake

Total Suspended Matter (August 2003)

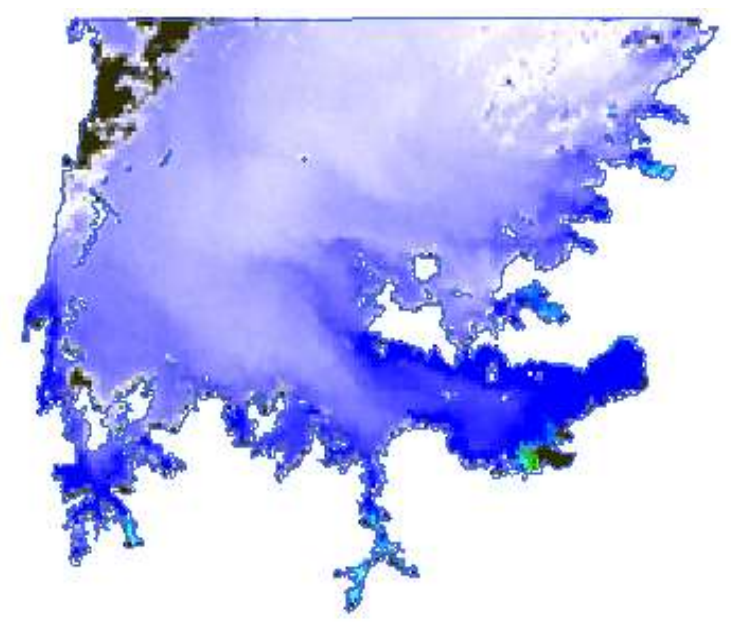

Total Suspended Matter (August2009)
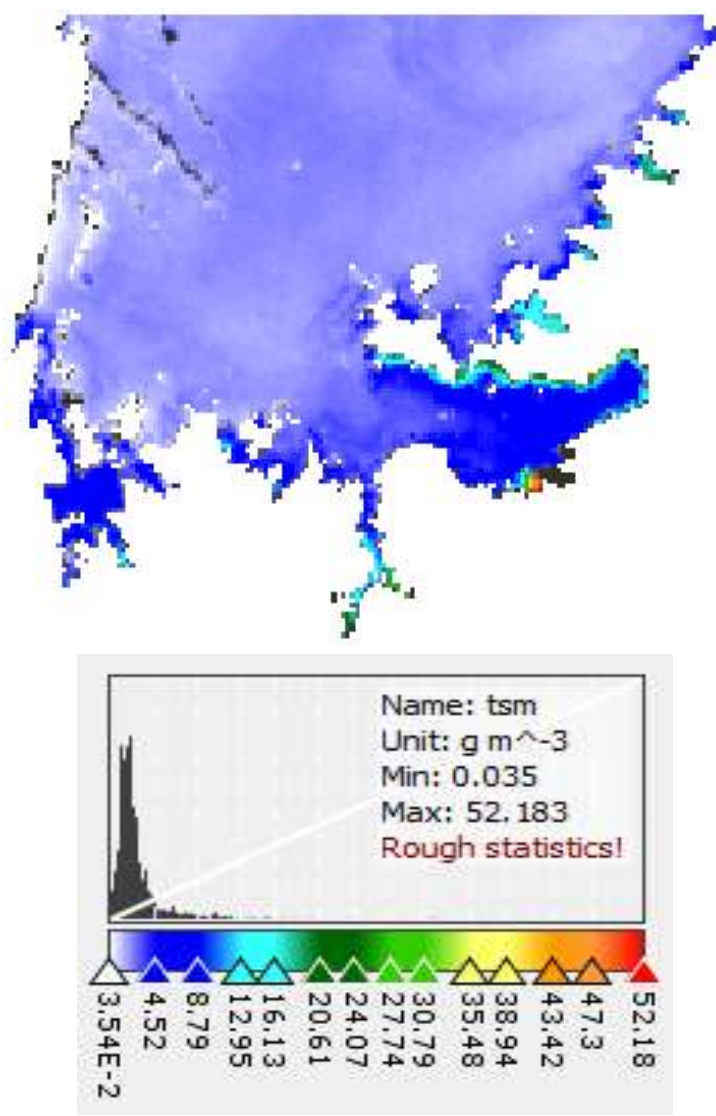

Total Suspended Matter (August 2006)

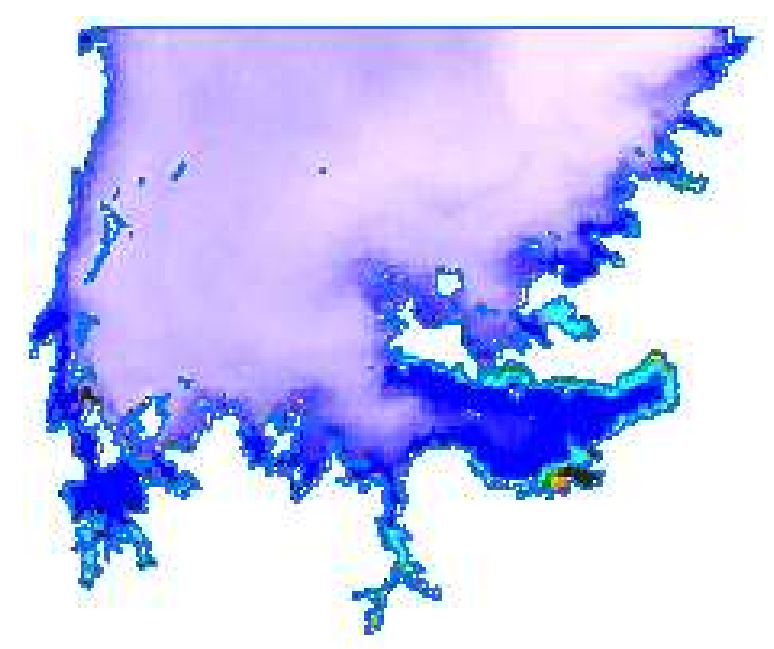

Total Suspended Matter (August2011)
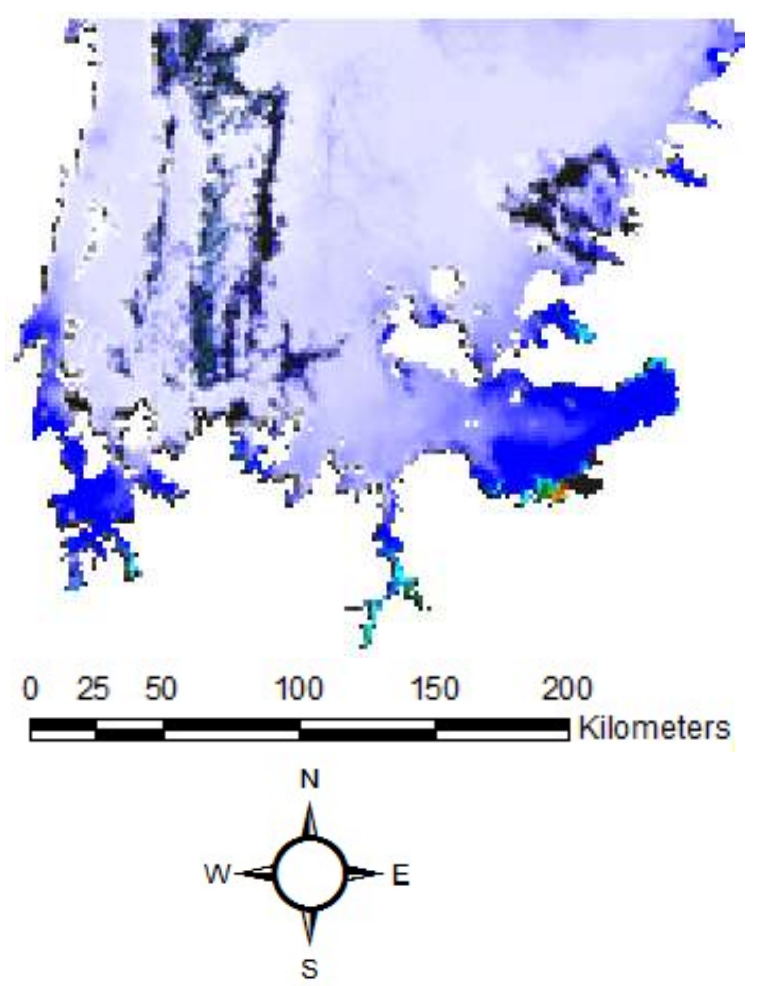

Figure 12: Spatial temporal variation of Total Suspended Matter in a lake 


\section{CONLUSIONS AND RECOMMENDATIONS}

\section{Introduction}

The study was conducted to assess the spatial temporal variation of selected water quality parameters in the Tanzanian side of Lake Victoria. Water quality parameters vary across different lake locations and with times. The water quality for the littoral zone was found to be more polluted than the pelagic zone. Although the water quality is still within the allowable receiving water standards, the water quality of the lake is deteriorating with time. This could be due to the activities taking place in the catchment area, especially agriculture, wastewater discharged from urban areas, invasion of wetlands for agriculture and deforestation. Therefore, if no action is put in place to rescue the situation, in long run, the water quality of the lake will be polluted above the allowable standard. However, the results are not conclusive as other parameters of water quality for the lake, including biological water quality parameters and heavy metals were not analyzed.

\section{Conclusions}

The assessed water quality parameters in the pelagic and littoral zones of the lake were found to vary with time and space. During the study period, the water quality of Lake Victoria was still within WHO limits. It generally complies with the Tanzania Bureau of standards for the receiving water bodies standards. The water on the littoral zone of the lake was found to be more polluted than in the pelagic zone for most of the parameters measured.

\section{Recommendation}

Although a lot of the efforts were made by LVEMP (and now LVBWO) to monitor the water quality of Lake Victoria, a robust, effective and efficient water quality monitoring programme (WQMP) should be set. The WQMP should take into consideration the seasonality effects (dry and wet) of sampling and the prescribed fixed depths of sampling should be emphasized. Currently, the sampling campaigns depend on the availability of funds. The existing WQMP should be reviewed to reflect its reality and appropriateness. This will give a good interpretation when someone plans to carry out an analysis of the data. Since the littoral zones are mostly polluted, thus they should be the priority pollution control intervention areas.

\section{ACKNOWLEDGEMENTS}

The authors would like to thank WaterNet for funding this study through the Masters Programme in Integrated Water Resources Management at the University of Zimbabwe and University of Dar es Salaam.

\section{REFERENCE}

Anhwange, B. A., Agbaji, E. B. and Gimba, E. C. (2012). Impact Assessment of Human Activities and Seasonal Variation on River Benue, within Makurdi Metropolis, International Journal of Science and Technology, 2(5): 248-254.

APHA. (2000). Standard Methods for Examination of Water and Wastewater. American Public Health Association, American Water Works Association, Water Control Federation: Washington. Araoye, P. A. (2009). The Seasonal Variation of $\mathrm{pH}$ and Dissolved Oxygen (DO) Concentration in Asa Lake Ilorin, Nigeria, International Journal of Physical Sciences, 4(5): 271-274.

Boström, B. (1981). Factors Controlling the Seasonal Variation of Nitrate in Lake Erken, International Review of Hydrobiology, 66(6): 821-836.

Bureau for Industrial Cooperation (BICO). (2020). Preparation of an Integrated Water Resource Management and Development Plan for the Lake Victoria Basin Report, Component 2: Policy, Laws and Institutional Framework 
Including

Socio-Economic

Assessment, Volume 2: Socio-

Economic Assessment.

Boehrer, B. and Schultze, M. (2008).

Stratification Lakes, Reviews of Geophysics, 46(2006): 1-27. DOI: 10.1029/2006RG000210.1.

Cheruiyot, E. K., Mito, C., Menenti, M., Gorte, B., Koenders, R. and Akdim, N. (2014). Evaluating MERIS-Based Aquatic Vegetation Mapping in Lake Victoria, Remote Sensing: 7762-7782. DOI: $10.3390 /$ rs6087762.

COWI Consulting Engineers. (2017). Water Supply and Sanitation for Mwanza Town and Satellite, Technical Assistance for Preparation of Master Plan.

COWI Consulting Engineers. (2002). The Integrated Water Quality/Limnology Study for Lake Victoria. Lake Victoria Environmental Management Project, Part II Technical Report.

Hua, A. K. (2017). Land Use Land Cover Changes in Detection of Water Quality: A Study Based on Remote Sensing and Multivariate Statistics, Journal of Environmental and Public Health, 2017. DOI:10.1155/2017/7515130.

Kateregga, E. and Sterner, T. (2007). Indicators for an Invasive Species: Water Hyacinths in Lake Victoria, Ecological Indicators, 7(2007): 362370.

Kateregga, E. and Sterner, T. (2009). Lake Victoria Fish Stocks and the Effects of Water Hyacinth, The Journal of Environment \& Development 18(1): 62-78,

DOI:

$10.1177 / 1070496508329467$.

Kayombo, S. and Jorgensen, S. E. (2006) Lake Victoria: Experience and lessons learned Brief, Lake Victoria, 44(November), pp. 431-446. DOI: 10.1007/3-540-32575-1.

Butler, B. A. and Ford, R. G. (2018). Evaluating Relationships between total Dissolved Solids (TDS) and Total Suspended Solids (TSS) in a MiningInfluenced Watershed, Mine Water
Environ, $\quad 37(1)$ : $\quad 18-30$. DOI:10.1007/s10230-017-0484-y.

Kibena, J., Nhapi, I. and Gumindoga, W. (2014). Assessing the Relationship between Water Quality Parameters and Changes in Landuse Patterns in the Upper Manyame River, Zimbabwe, Physics and Chemistry of the Earth, 6769(2014): 153-163. DOI: 10.1016/j.pce.2013.09.017.

Kimwaga, R. J., Mashauri, D. A., Bukirwa, F., Banadda, N., Wali, U. G. and Nhapi, I. (2011). Modelling of Non-Point Source Pollution Around Lake Victoria Using SWAT Model: A Case of Simiyu Catchment Tanzania, The Open Environmental Engineering Journal, 4: 112-123.

Lehman, J. T. and Branstrator, D. K. (1994). Nutrient Dynamics and Turnover Rates of Phosphate and Sulfate in Lake Victoria, East Africa, Limnology and Oceanography, 39 (1994): 227-233.

Scheren, P. A. G. M., Zanting, H. A. and Lemmens, A. M. C. (2002). Estimation of Water Pollution Sources in Lake Victoria, East Africa: Application and Elaboration of the Rapid Assessment Methodology, Journal of Environmental Management, 58(4): 235-248. 10.1006/jema.2000.0322.

National Aeronautics and Space Administration (NASA). (2006). CloudSat-CALIPSO, Delta II, Vandenberg, AFB, Calif, Launch Date: April. 28, 2006.

National Bureau of Statistics (NBS). (2012). The 2012 Population and Housing Census: Basic Demographic and Socio-Economic Profile.

Njuru, P. G. (2012). An Overview of the Present Status of Water Quality of Lake Victoria, Kenya. A Limnological Perspective. Available at: http://195.202.82.11:8080/xmlui/handl e/123456789/15.

Okungu, J. O., Njoka, S., Abuodha, J. O. Z. and Hecky, R. E. (2004). Chapter 1. An Introduction to Lake Victoria 
Catchment, Water Quality, Physical Limnology and Ecosystem Status (Kenyan Sector).

Oyoo, R. (2009). Deteriorating Water Quality in the Lake Victoria Inner Murchison Bay and its Impact on the Drinking Water Supply for Kampala, Uganda, $13^{\text {th }}$ World Lake Conference. Available at: http://wldb.ilec.or.jp/data/ilec/WLC13 Papers/others/3.pdf.

Pukate, Y. and Rim-Rukeh, A. (2008). Variability with Depth of Some Physico-Chemical and Biological Parameters of Atlantic Ocean Water in Part of the Coastal area of Nigeria, Journal of Applied Environmental Management, 12(1): 87-91. DOI: 10.4314/jasem.v12i1.55578.

Rather, I. A. and Dar, A. Q. (2020). Assessing The Impact of Land Use and Land Cover Dynamics on Water Quality of Dal Lake, NW Himalaya, India, Applied Water Science (2020) 10:219 DOI: 10.1007/s13201-02001300-5.

Schilling, K., Jha, M. K., Zhang, Y., Gassman, P. W. and Wolter, C. F. (2008). Impact of Land Use and Land Cover Change on The Water Balance of a Large Agricultural Watershed: Historical Effects and Future Directions, Water Resources Research, 44: W00A09. DOI: $10.1029 / 2007 \mathrm{wr} 006644$.

Sharma, R. C. and Tiwari, V. (2018). Seasonal Physico Chemical Characterization of Water of Sacred Lake Nachiketa Tal, Garhwal Himalay, Applied Water Science, 8: 164. DOI: 10.1007/s13201-018-0802-y.

Tadesse, I., Green, F. B. and Puhakka, J. A. (2004). Seasonal and Diurnal Variations of Temperature, $\mathrm{pH}$ and Dissolved Oxygen in Advanced Integrated Wastewater Pond System Treating Tannery Effluent, Water Research, 38(3): 645-654. DOI: 10.1016/j.watres.2003.10.006.
Tahiru, A. A., Doke, D. A. and Baatuuwie, B. N. (2020). Effect of Land Use and Land Cover Changes on Water Quality in the Nawuni Catchment of The White Volta Basin, Northern Region, Ghana, Applied Water Science, 10(198): DOI: 10.1007/s13201-020-01272-6.

Tanzania Standards (TZS 1130 (Part 1). (2008). ( $1^{\text {st }}$ Ed)-ISO 10304-1 2007: Water Quality-Determination of Dissolved Anions by Liquid Chromatography of Ions-Part 1: Determination of Bromide, Chloride, Fluoride, Nitrate, Nitrite Phosphate and Sulfate.

United Nations (UN). (2015). Sustainable Development Goals. Available online at https://sdgs.un.org/goals/goal6, Retrieved on 9th June 2015

UNEP (2006). Lake Victoria Basin Environment Outlook: Environment and Development. UNEP, Nairobi.

United States Geological Survey (USGS). Available online at http://glovis.usgs.gov.

WHO (2010). Nitrate and Nitrite in Drinking Water: 1-4. Available online at:

http://des.nh.gov/organization/commis sioner/pip/factsheets/dwgb/documents/ dwgb-3-9.pdf.

Wondie, A., Mengistu, S., Vijverberg, J. and Dejen, E. (2007). Seasonal Variation in Primary Production of a Large High-Altitude Tropical Lake (Lake Tana, Ethiopia): Effects of Nutrient Availability and Water Transparency, Aquatic Ecology, 41(2): 195-207. DOI: 10.1007/s10452-0079080-8.

Zang, C., Huang, S., Wu, M., Du, S., Scholz, M., Gao, F., Lin, C., Guo, Y. and Dong, Y. (2011). Comparison of Relationships Between $\mathrm{pH}$, Dissolved Oxygen and Chlorophyll for Aquaculture and Non-Aquaculture Waters, Water, Air, and Soil Pollution, 219(1-4): 157-174. DOI: 10.1007/s11270-010-0695-3. 